УДК 902

DOI: $10.18384 / 2310-676 \mathrm{X}-2021-5-36-64$

\title{
THE CULTURAL AND CHRONOLOGICAL CONTEXT OF SITES OF BUBANJ AND VELIKA HUMSKA ČUKA NEAR NIŠ (SOUTHEASTERN SERBIA) AND THEIR SIGNIFICANCE FOR UNDERSTANDING THE EMERGENCE AND DEVELOPIMENT OF THE CENTRAL BALKANS ENEOLITHIC
}

\author{
A. Bulatović, D. Milanović \\ Institute of Archaeology \\ Knez Mihajla ul. 35/4, Belgrade 11000, Republic of Serbia
}

\begin{abstract}
Aim. To elaborate the cultural and chronological context of two eponymous multilayered prehistoric sites in southeastern Serbia, in order to understand the eneolithisation process in the Central Balkans.

Methodology. The research is based on the methods of comparative analyses and synthesis, as well as the interpretation of the existing and fresh data acquired through archaeological excavations at the sites of Bubanj and Velika Humska Čuka near Niš. The following factors have been taken under consideration: geographic setting, resources, mutual spatial relations, stratigraphic characteristics, chronology, character of settlements during the Eneolithic, and other relevant data.

Results. The presented cultural and chronological contexts of the two researched sites, as well as other contemporary sites, compared to the pattern of the preceding Vinča settlements, indicated the character of changes that have occurred during the mid- $5^{\text {th }}$ millennium BC.

Research implications. The results of the research contribute to the perception of transformation processes within the Late Neolithic communities and the process of eneolithisation in the territory of the Central Balkans.
\end{abstract}

Keywords: Bubanj, Velika Humska Čuka, Central Balkans, $5^{\text {th }}$ and $4^{\mathrm{h}}$ millennium BCE, geographic setting, spatial relationship, stratigraphy, eneolithisation

\section{КУЛЬТУРНО-ХРОНОЛОГИЧЕСКИЙ КОНТЕКСТ ПАМЯТНИКОВ БУБАНЬ И ВЕЛИКА ХУМСКА-ЧУКА НЕДАЛЕКО ОТ НИША (ЮГО-ВОСТОЧНАЯ СЕРБИЯ) И ЕГО ЗНАЧЕНИЕ ДЛЯ ПОНИМАНИЯ ВОЗНИКНОВЕНИЯ ЭНЕОЛИТА ЦЕНТРАЛЬНЫХ БАЛКАН}

\author{
Булатович А., Миланович Д. \\ Институт археологии \\ 11000,г. Белград, ул. Князя Михайла, д. 35/4, Республика Сербия
}

\section{Аннотация}

Цель. Разработать культурный и хронологический контекст 2 одноимённых многослойных доисторических объектов на юго-востоке Сербии, чтобы понять процесс энеолитизации на Центральных Балканах.

Процедура и методы. Исследование основано на методах сравнительного анализа и синтеза, а также интерпретации существующих и свежих данных, полученных в ходе археологических

(ㄷ СС ВҮ Булатович А., Миланович Д., 2021. 
раскопок в местах Бубаня и Велика-Хумска-Чука близ Ниша. Были приняты во внимание следующие факторы: географическое положение, ресурсы, взаимные пространственные отношения, стратиграфические характеристики, хронология, характер поселений во время энеолита и другие соответствующие данные.

Результаты. Представленные культурно-хронологические контексты двух исследованных участков, а также других современных участков, по сравнению с рисунком предшествующих поселений Винча, указывали на характер изменений, произошедших в середине $V$ тысячелетия до н. э.

Теоретическая и/или практическая значимость. Результаты исследований способствуют восприятию процессов транссрормации внутри позднеолитических сообществ и процессу энеолитизации на территории Центральных Балкан.

Ключевые слова: Бубань, Велика Хумска-Чука, Центральные Балканы, V и IV тысячелетия, географическое положение, пространственные отношения, стратиграфия, энеолитизация

\section{Introduction}

The process of the formation of the Eneolithic in the territory of the Central Balkans has traditionally been associated with largescale migrations that marked the end of the Late Neolithic Vinča culture. According to such a scenario, groups of newcomers, bearers of the Bubanj-Salkuța-Krivodol cultural complex (hereinafter: BSK) inhabited the territory of the preceding communities of the Vinča culture and gradually repressed them $[1$, p. $204-205 ; 2 ; 3$, p. $28 ; 4$, p. $158-$ 159]. The majority of authors consider that the aforementioned cultural complex was formed within the territory of western Bulgaria, on the core of the Gradešnica culture, between 4500 and $4400 \mathrm{cal} \mathrm{BCE} \mathrm{[5;} \mathrm{6;} \mathrm{7].} \mathrm{Its}$ gradual expansion towards the north and east encompassed primarily the areas of present-day southeastern Romania and eastern Serbia, which consequently constrained the territory of the Vinča culture. The key arguments for such a violent end of the Neolithic settlements were increased frequencies of settlements on raised grounds, on naturally fortified places, the so-called Gradina settlements, fortification features (ditches and palisades), and burnt final habitation horisons [4, p. 158-159]. It has previously been considered that life in most of the Vinča settlements ended between 4650 and $4550 \mathrm{cal}$ BCE $[4 ; 8]$, and such high dates for the end of the Vinča culture resulted in a hiatus between the final horison of Vinča settlements and early BSK settlements. Furthermore, early BSK settlements, which could serve as a cause for an almost synchronous end of life in many Vinča settlements, have not been recorded in Serbia and Romania [5; 7]. However, new radiometric measurements have indicated a prolonged duration of the Vinča culture in certain micro-regions (up to approximately 4400 cal BCE $)^{1}[9 ; 10]$, compared to the previous stance of $\mathrm{D}$. Borić. Likewise, fresh data indicate that early BSK settlements have existed in the territories of both Serbia and Romania ${ }^{2}$ [10].

Recent research suggests that Vinča settlements have rarely been formed on dominant and rasied ground, while it seems like the number of such settlements gradually increases, although their chronology is often unknown $[11 ; 12]$, and the material culture resembles the earliest BSK settlements, which aggravates the precise cultural distinction [10]. What is certain is that during the BSK cultural complex (4500-3800/3700), the number of such settlements increases $[12 ; 13]^{3}$. Apparently, the fortifications repre-

\footnotetext{
Milanović D. The Copper Age in the Central Balkans. In: Parkinson W. A., Gyucha A., Galaty M., eds. Oxford Handbook of Balkan Prehistory. Oxford, Oxford University Press (готовится к печати в 2022 г.).

Там же.

3 Milanović D. Centralni Balkan u 5 milenijumu pre n. e: obrasci naseljavanja i društveno-ekonomske promene. Unpublished $\mathrm{PhD}$ thesis, University of Belgrade, Faculty of Philosophy, Belgrade, 2017; Milanović D. The interply between lowland and highland zones: Engaging the landscape of eastern Serbia and western Bul-
} 
sent a characteristic of the Vinča settlements starting from the Early Vinča (Vinča A-B), and a similar trend amplifies during the Late Vinča (Vinča C-D) and continues during the BSK period $^{1}[4$, p. $166-169 ; 14$, p. 201-238; $15]$, especially considering the fact that naturally fortified and elevated plateaus of topographically limited sites should likewise be considered as elements of fortifications [16]. Besides, burnt habitation horisons are characteristic for most of the Vinča and BSK settlements, as it remains unclear whether the burning represents a part of a ritual and a social act connected with the practice of abandoning of parts or entire settlement and/or conflicts and intentional fires $[4, \text { p. 166 }]^{2}$. However, it seems as if the complex process of transformation of the Vinča culture included a series of internal and external factors [4, p. 159-162], which have led to the gradual abandonment of long-lasting large settlements, micro-regions, and regions, and the formation of the new cultural milieu of the Copper $\mathrm{Age}^{3}$. Such a new cultural environment implied smaller and spatially closer settlements, increased inhabitation of dominant high grounds, and the establishment of new relations between the settlement and

garia in the second half of the 5th millennium BCE. In: Gori M., Hellmuth-Kramberger A., Krapf T., Recchia G., eds. Archaeology of Mountainous Landscapes in Balkan Prehistory. Universitätsforschungen zur prähistorischen Archäologie, Rudolf Habelt, Bonn (готовится к печати в 2022 г.).

Milanović D. The Copper Age in the Central Balkans. In: Parkinson W. A., Gyucha A., Galaty M., eds. Oxford Handbook of Balkan Prehistory. Oxford, Oxford University Press (готовится к печати в 2022 г.); Milanović D. The interply between lowland and highland zones: Engaging the landscape of eastern Serbia and western Bulgaria in the second half of the 5th millennium BCE. In: Gori M., Hellmuth-Kramberger A., Krapf T., Recchia G.,eds. Archaeology of Mountainous Landscapes in Balkan Prehistory. Universitätsforschungen zur prähistorischen Archäologie, Rudolf Habelt, Bonn (готовится к печати в 2022 г.).

2 Milanović D. Centralni Balkan u 5 milenijumu pre n. e: obrasci naseljavanja i društveno-ekonomske promene. Unpublished PhD thesis, University of Belgrade, Faculty of Philosophy, Belgrade, 2017 p. 274-275, 286.

3 Milanović D. The Copper Age in the Central Balkans. In: Parkinson W. A., Gyucha A., Galaty M., eds. Oxford Handbook of Balkan Prehistory. Oxford, Oxford University Press (готовится к печати в 2022 г.). social groups, which included more frequent conflicts $[13 ; 17 ; 18]^{4}$, the increased significance of stockbreeding, the increased significance of new crafts, especially metallurgy of copper, gold and other metals, enhanced social mobility and reorganization of trade networks $[19 ; 20 ; 21 ; 22 ; 23 ; 24]$. Such a cultural environment or the process of eneolithisation has been perceived in this paper through the example of the settlement dynamics of two eponymous multilayered sites, Bubanj and Velika Humska Čuka near Niš (southeastern Serbia), during the Eneolithic of the Central Balkans.

\section{The geographic setting, resources, and spatial relations between Bubanj and Velika Humska Čuka}

The sites of Bubanj in Novo Selo and Velika Humska Čuka in Hum are located within the Nišava and South Morava confluence zone, in the proximity of the present-day city ofNiš. Geomorphologically, the area represents a part of the Niš Basin which stretches between the Seličevica Mountain and Jastrebac-Kalafatbarrier (fig. 1).

The Niš Basin is approximately $44 \mathrm{~km}$ long, $22 \mathrm{~km}$ wide, and it encompasses an area of $630 \mathrm{~km}^{2}$. The wider area in which the sites of Bubanj and Velika Humska Čuka are located lies within the Serbian-Macedonian Mass. The terrain is primarily comprised of crystalline shales, covered by volcanic sediments of the Lece region and the Neogenic sediments represented by systems of ditches and valleys of the South Morava River and its tributaries. The Nišava River is the largest tributary to the South Morava River, in

\footnotetext{
4 Milanović D. Centralni Balkan u 5 milenijumu pre n. e: obrasci naseljavanja i društveno-ekonomske promene. Unpublished $\mathrm{PhD}$ thesis, University of Belgrade, Faculty of Philosophy, Belgrade, 2017; Milanović D. The interply between lowland and highland zones: Engaging the landscape of eastern Serbia and western Bulgaria in the second half of the 5th millennium BCE. In: Gori M., Hellmuth-Kramberger A., Krapf T., Recchia G.,eds. Archaeology of Mountainous Landscapes in Balkan Prehistory. Universitätsforschungen zur prähistorischen Archäologie, Rudolf Habelt, Bonn (готовится к печати в 2022 г.).
} 

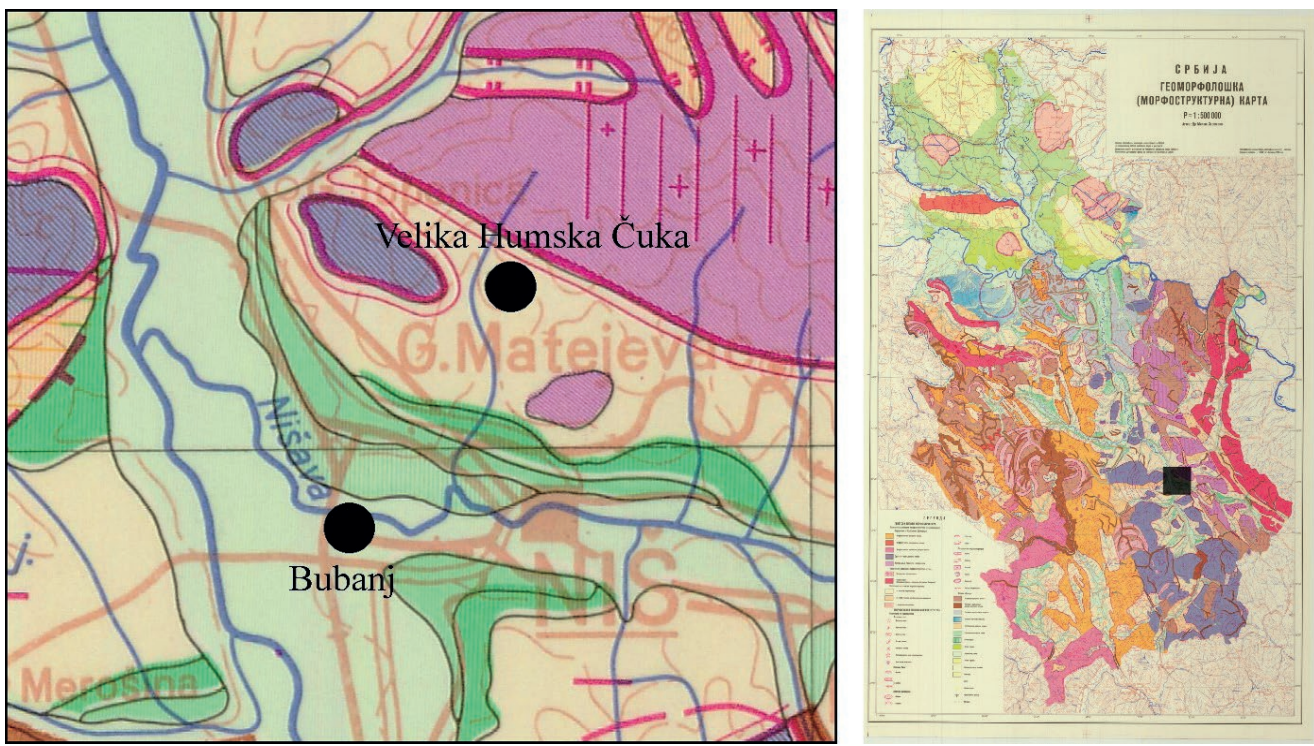

Fig. 1 / Pис. 1. Geomorphological map of Serbia (Zremski) with the highlighted area of southeastern Serbia and the positions of sites of Bubanj and Velika Humska Čuka / Геоморфологическая карта Сербии (Зремски) с выделенной областью юго-востока Сербии и положениями памятников Бубань и Велика Хумска Чука

Источник: данные авторов

which it inflows some $10 \mathrm{~km}$ downstream of Niš. The river springs in Bulgaria, below Mali Kom $(1840 \mathrm{~m})$, and its flow, which follows the southeast-northwest direction, encompasses a total of $218 \mathrm{~km}^{2}$ [25, p. 33]. Nišava runs through a wide valley where it meanders due to small river fall, and through narrow gorges with significantly higher river fall.

The archaeological site of Bubanj is located $5 \mathrm{~km}$ west of the city of Nišs, on the western fringe of the lowest river terrace, next to the wide alluvial plain of the South Morava River, approximately $7 \mathrm{~km}$ southeastern of the confluence of Nišava and South Morava rivers (fig. 1-2).

An ellipsoid loess elevation with an altitude of $198 \mathrm{~m}$, oriented northwest-southeast, with a length of more than $300 \mathrm{~m}$ and a width up to $170 \mathrm{~m}$, has once risen within the vast plain, exceding the surrounding terrain up to $15 \mathrm{~m}$ in height. Formerly, the Nišava River flowed next to the site, on its northern side, but following the melioration during the 60 s of the $20^{\text {th }}$ century, the river flow has been altered as it now runs further north of the site. In the course of archeological excavations in 1935 and between 1954 and 1958, all three plateaus of the site were preserved: eastern (approximate surface of $0.85 \mathrm{ha}$ ), central (approximate surface of $0.3 \mathrm{ha}$ ), and the smallest, western (approximate surface of $0.09 \mathrm{ha}$ ). Those plateaus, together with the surrounding slopes of the site, covered an area of approximately 5 ha. The southern and western slopes were the most accessible, while the eastern slope connected the site with the river terrace. The northern side of the site, towards the Nišava River, was inaccessible due to the degree of slope, while the mild slope in the west led towards the confluence of Nišava and South Morava rivers. The eastern portion of the location, within a width of $80 \mathrm{~m}$, was damaged by railroad construction even before the first excavations in 1935, and it was almost completely devastated in the second half of the $20^{\text {th }}$ century by the construction of the highway and the accompanying bypass. Currently, solely the northeastern portion of the site, with a length of around $70 \mathrm{~m}$ and a width of approximately $5 \mathrm{~m}$ remains preserved, repre- 


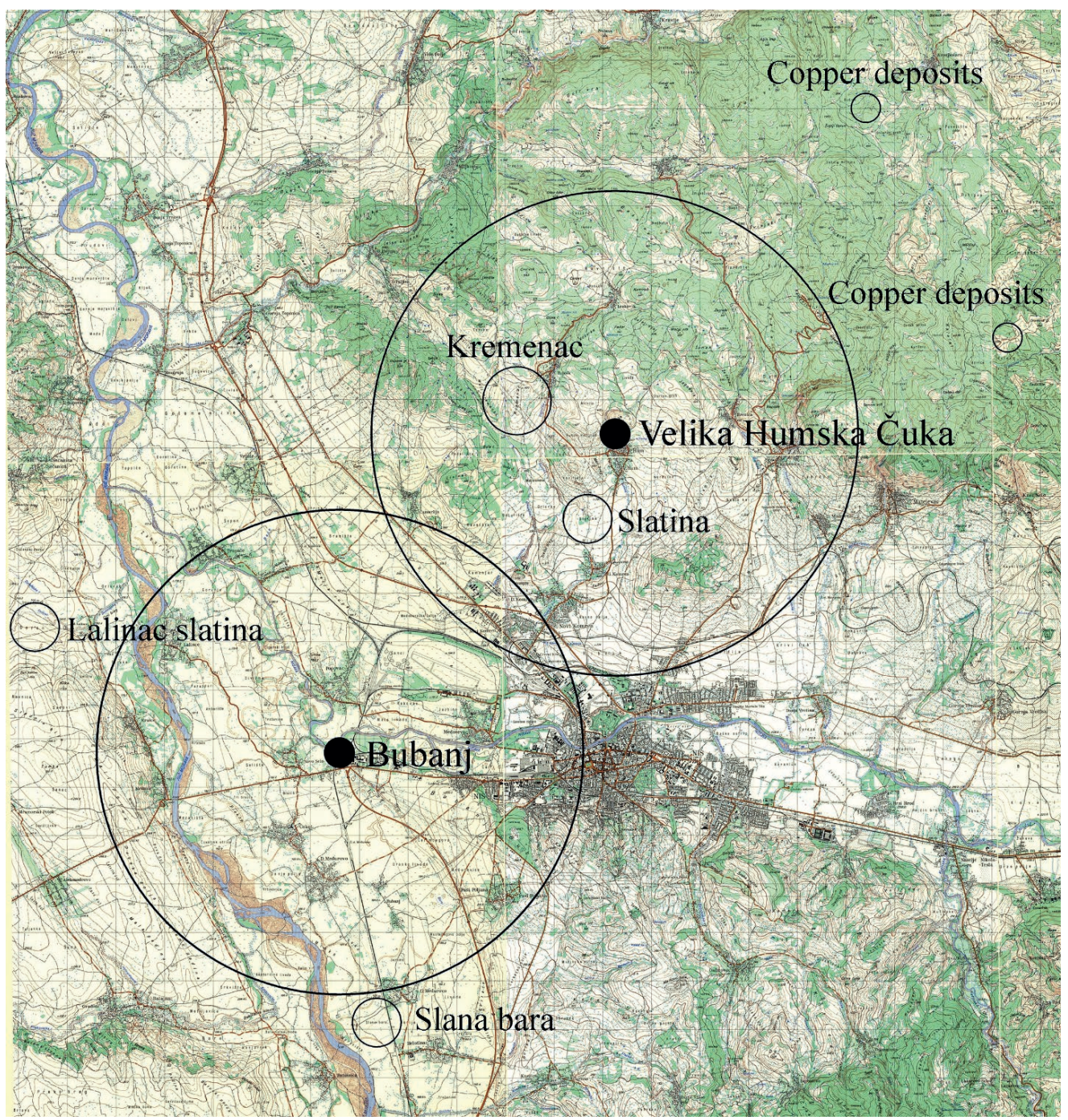

Fig. 2 / Pис. 2. A topographic map with the positions of sites of Bubanj and Velika Humska Čuka, toponyms that indicate salinated soils and saltwater springs, deposits of flint and copper / Топографическая карта с расположением стоянок Бубань и Велика Хумска Чука, топонимы, обозначающие засоленные почвы и источники соленой воды, месторождения кремня и меди

Источник: данные авторов

senting less than $1 \%$ of the former surface of the site. The construction of modern infrastructure and Penitentiary southern and eastern of the site, the territorial expansion of the village of Novo Selo towards the west and south of the site during the second half of the $20^{\text {th }}$ and the $21^{\text {st }}$ century, as well as the aforementionedshifts of the river flow, have significantly altered the former surroundings of the site.
In terms of geology, the immediate vicinity of the site of Bubanj (within a diameter of $10 \mathrm{~km}$ ), lies on alluvial sediments, while the hinterland is represented by conglomerates, sandstones, sands, marls, limestones, and clays. Judging by geological and topographic characteristics of the surrounding terrain, the settlement at the site of Bubanj was oriented towards river terraces on the east and southeast, and the alluvial plain on 
the west, north, and northwest. Due to numerous meanders of the Nišava River before the aforementioned melioration during the second half of the $20^{\text {th }}$ century, a marshy environment was represented. Three types of soil are present in the territory of the site of Bubanj, within a diameter of $10 \mathrm{~km}$ : fluvisol is the most represented, followed by vertisol, and eutric cambisol as the least represented type of soil (fig. 3).

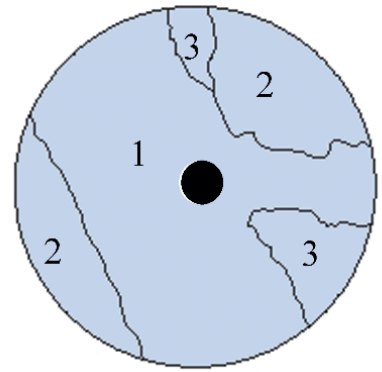

Bubanj, Niš district

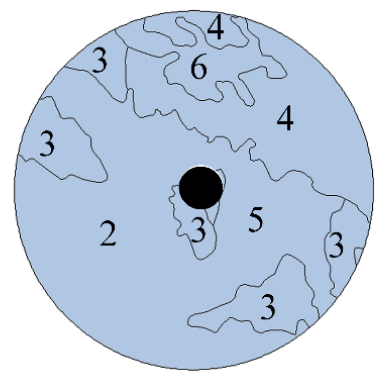

Velika Humska Čuka, Niš district

\section{Legend}

1. Fluvisol, 2. Vertisol, 3. Eutric cambisol, 4. Calcocambisol and calcomelanosol, 5. Calcomelanosol, regosol and lithosol on limestone, 6. Ranker, regosol and lithosol on sandstone, flysch and chert

Fig. 3 / Рис. 3. Pedology of sites of Bubanj and Velika Humska Čuka within a $10 \mathrm{~km}$ diameter / Почвоведение памятников Бубань и Велика Гумска Чука в пределах 10 км в диаметре

Источник: данные авторов

The site of Velika Humska Čuka is located on a dominant elevated plateau on the northeastern periphery of the village of Hum, approximately $7 \mathrm{~km}$ north of Niš (fig. 1-2). The plateau itself is comprised of four terraces, each on a different height level. The length of the site in the east-west direction is approximately $200 \mathrm{~m}$ and the width of the site in the north-south direction is approximately $160 \mathrm{~m}$, measuring a total surface of around 3 ha. The highest point on the central and also the smallest plateau lies at the altitude of $454.79 \mathrm{~m}$. Each of the aforementioned terraces is some $5 \mathrm{~m}$ lower than the previous one, and the lowest terrace lies at the altitude of 435-440 m. The Hum River, nowadays a rivulet, surrounds the site on its northern and western sides. Due to vertical slopes, all of the sides of the site are hardly accessible, save for the northern, which is through a smaller saddle connected with the neighboring Mala Humska Čuka. The elevation of the central plateau, compared to the bank of Hum rivulet $(333 \mathrm{~m})$ is $121,79 \mathrm{~m}$. Several cavelets have been recorded beneath the central plateau, on the western portion of the site, at the altitude of approximately $400 \mathrm{~m}$.

Geologically, the narrower and wider zone of the site is comprised of Miocene formations of sandstones, bituminous shales, and marls. On the other hand, the area east of the site (and further to the south and west) is represented by formations of conglomerates, sandstones, sands, marls, limestones, and clay, while the hinterland is also covered with dolomites, shales, and cherts. The site lies directly on calcomelanosols (calcareousdolomite chernozem), regosol, and orthents on limestone. An area covered with eutric cambisol is present in the southern side of the site, while the hinterland of the site is covered with significant areasof vertisol, calcocambisol (brown soil on limestone and dolomite), and calcomelanosol (fig. 3). 
The existence of toponyms that indicate surfaces with saline soils and springs of saltwater in the wider area or the periphery of the researched territory (within a diameter of $10 \mathrm{~km}$ ) of the sites of Bubanj (Slana Bara, Slatina 1 and Slatina in Lalinac) and Velika Humska Čuka (Slatina 1) point to the importance of animal husbandry and hunting in those settlements and the possibility of salt procurement for both human and animal diet (fig. 2).

Velika Humska Čuka lies 8.5 km northeast of Bubanj. Flint deposits are represented at the Kremenac location which lies $2.1 \mathrm{~km}$ west of the site in the village of Hum, and it is considered that those deposits were exploited in prehistory [26, p. 289-290; 27; 28], while copper deposits are located $8.3 \mathrm{~km}$ northeastern of the site. Claypits in the vicinity of both sites (one about $300 \mathrm{~m}$ from Velika Humska Čuka and one near Bubanj) point out the possibility that the population from those sites was using those pits for pottery production.

\section{The history of research and stratigraphy}

The importance of previous excavations is reflected in the fact that materials uncovered at the sites of Bubanj and Velika Humska Čuka, and publication by A. Oršić Slavetić in 1940 have served M. Garašanin to define two phases of the Bubanj-Hum group of the Central Balkans on the $3^{\text {rd }}$ International Congress of Prehistorians in Zurich in 1950, prior to his excavations $[29$, p. 8]. M. Garašanin conducted archaeological excavations at the site of Bubanj between 1954 and 1958, and at the site of Velika Humska Čuka in 1956, whichenabled him to define and further elaborate the cultural development of the Bubanj-Hum group $[30 ; 31 ; 32 ; 33 ; 34]$, and subsequently provide certain complements and modifications according to the new data on the Eneolithic cultures of the neighboring regions [29, p. 8-16; 35, p. 154-166].

\section{The site of Bubanj}

Six cultural horisons were recorded at the site of Bubanj following Oršićs (1937) and
Garašanin's excavations (1954-1958) [36; 37, p. 246-247]. A total of more than $520 \mathrm{~m}^{2}$ have been excavated. The following cultural horisons have been recorded:

1. Starčevo-Middle Neolithic;

2. Bubanj-Hum Ia, i. e. Bubanj-KrivodolSălcuța cultural complex - Early Eneolithic;

3. Bubanj Ib, i. e.Cernavodă III-BolerazBaden cultural complex - Middle or Late Eneolithic;

4. Bubanj-Hum Ib, i. e. early southern variation of the Coțofeni culture, early Kostolac and Baden cultures - Late Eneolithic;

5. Bubanj-Hum II, i. e. late southern variant of the Coțofeni culture, late Kostolac culture, and certain elements from the southeast (Dikili Tash and Sitagroi in northeastern Greece) and the northwest (Vučedol culture) - Late Eneolithic;

6. Bubanj-Hum III - Early BronzeAge, i. e. late Glina culture.

The final research campaigns at the site of Bubanj were conducted in a period between 2008 and 2014 by the Institute of Archaeology in Belgrade and the National Museum in Niš. In the course of this period, a surface of approximately $150 \mathrm{mI}$ was investigated on a small remaining part of the site on the eastern plateau. The length of the dig, which was organized in three trenches, was $24 \mathrm{~m}$, and the width up to $6.5 \mathrm{~m}$. A total of five cultural layers (six, in fact, considering that the youngest layer $\mathrm{V}$ is separated into upper and lower portion) with at least eleven settlement horisons (Starčevo-level I, Bubanj-Hum Ia-levels IIa-c, Bubanj Ib-Cernavodă IIIBoleraz-Baden cultural complex - levels IIIa-b, Bubanj-Hum Ib-levels IVa-c, Bubanj-Hum II-lower level V and BubanjHum I-upper level V) were recorded in a layer of up to $2.7 \mathrm{~m}$ of depth. The latest excavations in the eastern plateau have enabled the separation of 11 settlement horisons, and the finds indicate the existence of Middle Bronze Age, Late Bronze Age and Early Iron Age horisons, as well as a Modern Age necropolis. Those excavations implied detailed analyses of Early Eneolithic settlement patterns in the Niš Basin, results of previous 
excavations, stratigraphy, and chronology of the site, pottery, chipped stone and bone industry, animal and plant remains [37]. Of significant importance are the results of the dating of Eneolithic and Early Bronze Age contexts which provided the first chronological framework for certain cultural manifestations in southeastern Serbia and enabled the comparison with dates from the excavated settlements in western Bulgaria and the surrounding regions $[38 ; 39 ; 40]$.

\section{The site of Velika Humska Čuka}

The first mention of the site, as a Neolithic, comes from the survey reports of V. Fewkes [41]. The first archaeological excavations at the site of Velika Humska Čuka were conducted in 1932 and 1933 by the National Museum in Niš and continued in 1934 by V. Grbić, who attributed the site to the Bronze Age. The excavations were continued in the following years, although the results have never been published. The continuation of excavations in 1956 enabled the separation of a specific prehistoric phase marked as the Bubanj-Hum group [42]. Judging by the plan that was published in 1959, the excavations were conducted on the first and the second terrace [42, fig. 1].

The total depth of the archaeological layer varied between 0.9 and $1.2 \mathrm{~m}$ [42, fig. 2-3]. Different stratification was caused by the fall of the terrain from the north towards the south, and the difference in the thickness of cultural layers was caused by erosion and digging of later structures from historical periods. During the earlier excavations, a total of two cultural layers have been separated in the stratigraphy of the site, both with a different degree of preservations and depth. The first cultural layer contained mixed material from the Eneolithic, Bronze Age and historical periods, and the older cultural layer contained the Early Eneolithic Bubanj-Hum Ia material [42, p. 245). A total of four phases of settling have been separated (Early Eneolithic Bubanj-Hum Ia phase, Bronze Age - the so-called Slatina group, Roman phase, and Medieval-Slavic phase), while certain activi- ties and phases were presumed based on the scarce material (Late Eneolithic Bubanj Hum Ib phase, i. e. Baden-Kostolac, Late Eneolithic/Early Bronze Age Bubanj-Hum II phase, Early Bronze Age Bubanj-Hum III phase, Early Iron Age and La Téne periods) [42, p. 245-249].

The archaeological excavations conducted by the Institute of Archaeology in Belgrade and the National Museum in Niš in 2009 and between 2014 and 2021, covered an area of $530 \mathrm{~m}^{2}$ within the eastern portion of the site, on the fringe of the second terrace [43, fig. 1]. The depth of the cultural layer at the plateau measures up to $2 \mathrm{~m}$. The recorded remains of settlement structures and portable archaeological finds indicated the existence of at least 11 habitation horisons:

1. Early Eneolithic Bubanj-Hum Ia phase;

2. Late Eneolithic Bubanj-Hum Ib phase i. e. Late Kostolac-Coțofeni;

3. Late Eneolithic/Early Bronze Age Bubanj-Hum II phase;

4. Early Bronze Age Bubanj-Hum III phase;

5. Middle Bronze Age;

6. Late Bronze Age;

7. Early Iron Age;

8. Later phases of the Early Iron Age $\left(5^{\text {th }} / 4^{\text {th }}\right.$ century BC);

9. La Téne III phase;

10. Antique (Roman) Period ( $2^{\text {nd }}$ $3^{\text {rd }}$ century AD);

11. Late Antique-Early Byzantine Period $\left(4^{\text {th }}-5^{\text {th }}\right.$ century AD).

The earliest prehistoric layers were more or less damaged by digs from later prehistoric periods and especially the Late Antique Period.

\section{The chronology and the settlement character during the Eneolithic at the site of Bubanj \\ Early Eneolithic \\ (ca. 4500/4400-3800/3700 cal BCE)}

The archaeological excavations at the site of Bubanj have pointed out that two out of three plateaus at the site were inhabited 
during the Early Eneolithic. The smallest western plateau, yielded no remains of above-ground structures, while previous excavations recorded the remains of a stone ring, which together with the topographic characteristics of the terrain (circular form and emphasized sloping of the terrain) indicate its defensive function [36, p. 55]. On the largest, eastern plateau, two Early Eneolithic horisons, with a depth between 1.2 and $1.4 \mathrm{~m}$, were registered during the excavations by A. Oršić Slavetić (levels A and B) and later by M. Garašanin (levels V-IV) $[29 ; 35 ; 36 ; 44$, p. 14]. Latest excavations have pointed out that a portion of the plateau (or perhaps the entire plateau) was encircled by a deep ditch with a deposit of compact soil on its inner side, which might have served as a rampart. Remains of habitation horison $\mathrm{C}$ were recorded in the central plateau. The level is represented by an earlier horison with above-ground structures possibly separated in at least two phases, and a younger horison represented by pits. The depth of the layer was up to $0.5 \mathrm{~m}$. Levels with burnt structures in the eastern plateau built in wattle and daub technique, of which one measured the dimensions of $8 \times 4 \mathrm{~m}$ (outer dimensions) (Oršić's level A) could represent the parts of simultaneous settlement (Oršićs level A and Garašanin's level V, i. e. Oršićs level $B$ and Garašanin's level IV), while level $\mathrm{C}$ on the central plateau was represented by unburnt structures build in different technique (the foundation of walls into deep ditches and the utilization of stone as a building material in the upper portions of the structures). The inner dimensions of three partially excavated structures on the central plateau are approximately $6.4 \times 5.5 \mathrm{~m}$. A foundation wall of a palisade, with an emphasized function of protection from the northern winds, was recorded in the vicinity of the aforementioned structures [29, p. 11].

The latest research has confirmed that during the Early Eneolithic, the preserved portion of the eastern plateau hosted structures built in wattle and daub technique (without foundation ditches and stone as building material), although no significant remains of burnt daub have been recorded. Several structures with post holes, that had economic and possibly residential character, were recorded within three building horisons of the cultural layer II, with a depth of around $1.35 \mathrm{~m}$ [37, p. 69-90]. According to the distribution of finds, it has been suggested that the other features within the excavated area (oven, pits, and ditch) served as working areas in which the most prominent activities were connected with preparation for weaving, weaving, and the production of utility products made of leather and fur [37, p. $162-166$, tab. $7,13,14)$. Additionally, six available AMS dates indicate that three building horisons within the excavated portion of the eastern plateau originate from a relatively short period withinone to two centuries between 4343 and 4262 cal BCE (68.2\% probability) and 4351 and 4245 cal BCE (95.4\%) (tab. 1/6-10). Therefore, it remains unclear whether the remains of the Early Eneolithic settlement in the eastern and central plateau are concurrent or represent settlements from different phases of development of the BSK cultural complex. The existence of the early phase of the BSK complex at the neighboring site in Hum [10, p. 19, fig. 8], might indicate that the phase was present at Bubanj as well and that it could be represented within Garašanin's level $\mathrm{C}$ at the central plateau. On the other hand, if the remains of settlements on the central and eastern plateau are concurrent, it would indicate social segregation within a larger settlement, which would in this case encompass both plateaus. An absolute date that originates from the lower portions of a deep Late Eneolithic pit, which might indicate the possibility of settling at the site of Bubanj between the $40^{\text {th }}$ and the $39^{\text {th }}$ century $\mathrm{BC}$, is quite representative of the development and chronology of the Early Eneolithic at the site (tab. 1/12). During the excavations, no features or cultural layers which would correspond to that period were recorded, although certain stylistic and typological characteristics were noted on a series of potsherds, which draw parallels in 
period-related cultural groups of the Lower Danube Region, such as Salcuta IV, Galatin, Cernavodă I and others [45, p. 131, fig. 1/1; 36 , cat. number 77 ; 37, Pl. 3/1, 5; Pl. 6/1, 5; Pl. 16; Pl. 17/1, 9, 10, 13, 15]. However, the aforementioned absolute date does not automatically imply that the sample (a river shell valve) was utilized by humans, since those are used both in human and animal diet, and the sample could have been brought to the site in that manner, especially considering the former proximity of the Nišava River to the site. Numerous finds of chipped stone tools (primarily blades) and cores, grinding stones, ceramic weights, and spindle whorls represent a prominent characteristic of the Early Eneolithic habitation horisons at the site. Additionally, finds of ceramic and bone anthropomorphic figurines, ceramic altars and palettes, ceramic vessels coated with golden dust, painted with pasty colors (usually red) and graphite, marine shell jewelry, and copper tools, are all important. Likewise, several features containing a significant number of completely preserved yet broken ceramic vessels have been recorded, as well as several features containing a large number of stone objects, bone tools, and pottery. Pottery from all of the horisons of the cultural layer II is characteristic for the Bubanj-Hum I group, meaning the BSK cultural complex (pl. 1).

Bowls, beakers, amphorae, pots, and lids comprise most of the recorded vessels from the Early Eneolithic features at the site of Bubanj, while beakers on a foot, cups, strainers, miniature vessels, altars, and vessels with a handle on the bottom comprise a total of $3 \%$. Bowls represent the most numerous forms of ceramic vessels. The most represented are bowls with an inverted rim, followed by conical bowls with a thickened rim, conical, semi-globular, globular, and biconical bowls. In terms of quantity, the beakers represent the second group of vessels, amphorae the third, and pots the fourth. Channeling and barbotine ornamentation are the most common decoration techniques. Other represented decoration techniques are incising, impressing,red color painting, grooving, graphite painting, notching, and ornamentation comprised of burnished lines, modeled bands and ribs, and a bicolored outer surface of the vessel.

\section{Middle Eneolithic (ca. 3600/3500- $3300 / 3200$ cal BCE)}

During the earlier excavations, remains of the settlement from the middle or early phase of the Late Eneolithic period, which was connected with the Cernavodă IIIBoleraz cultural complex (the Bubanj Ib group), were confirmed in Garašanin's level III on the eastern plateau [36, p. $54 ; 46 ; 47)$. The discovered structure, which was probably burnt, was built in the wattle and daub technique. Finds from this period were also recorded in Oršićs trenches, and his level C could be related to Garašanin's level III. Finds from the trenches on the central plateau from 1957 and 1958 confirm the activities from the same period.

In the course of research between 2008 and 2014 cultural layer III with 2 horisons, which was attributed to the Middle Eneolithic period, with pottery whose stylistic and typological elements correspond to both Cernavoda III-Boleraz and Baden groups was registered. In line with that, the authors suggested a new term for the Middle Eneolithic of the Central Balkans - Cernavoda III-Boleraz-Baden cultural phenomenon (hereafter: CVIII-B-B) [37]. The remnants of afloor made of burnt soil, one storage pit, and several waste pits were recorded in the earlier horison of this layer. Interestingly, a completely preserved amphora with a small number of various plant residues was recovered in situ in the storage pit. The remains of a floor substructure indicate the existence of a kiln in this period, yet, based on finds from both of the horisons, this part of the settlement was not utilized for habitation, but rather for waste disposal and storage, which indicates that the settlement was located in the immediate vicinity, probably somewhat to the south. This is further confirmed by numerous finds of house daub in structures and the layer from this period, as well as a structure made of wattle and daub which was 


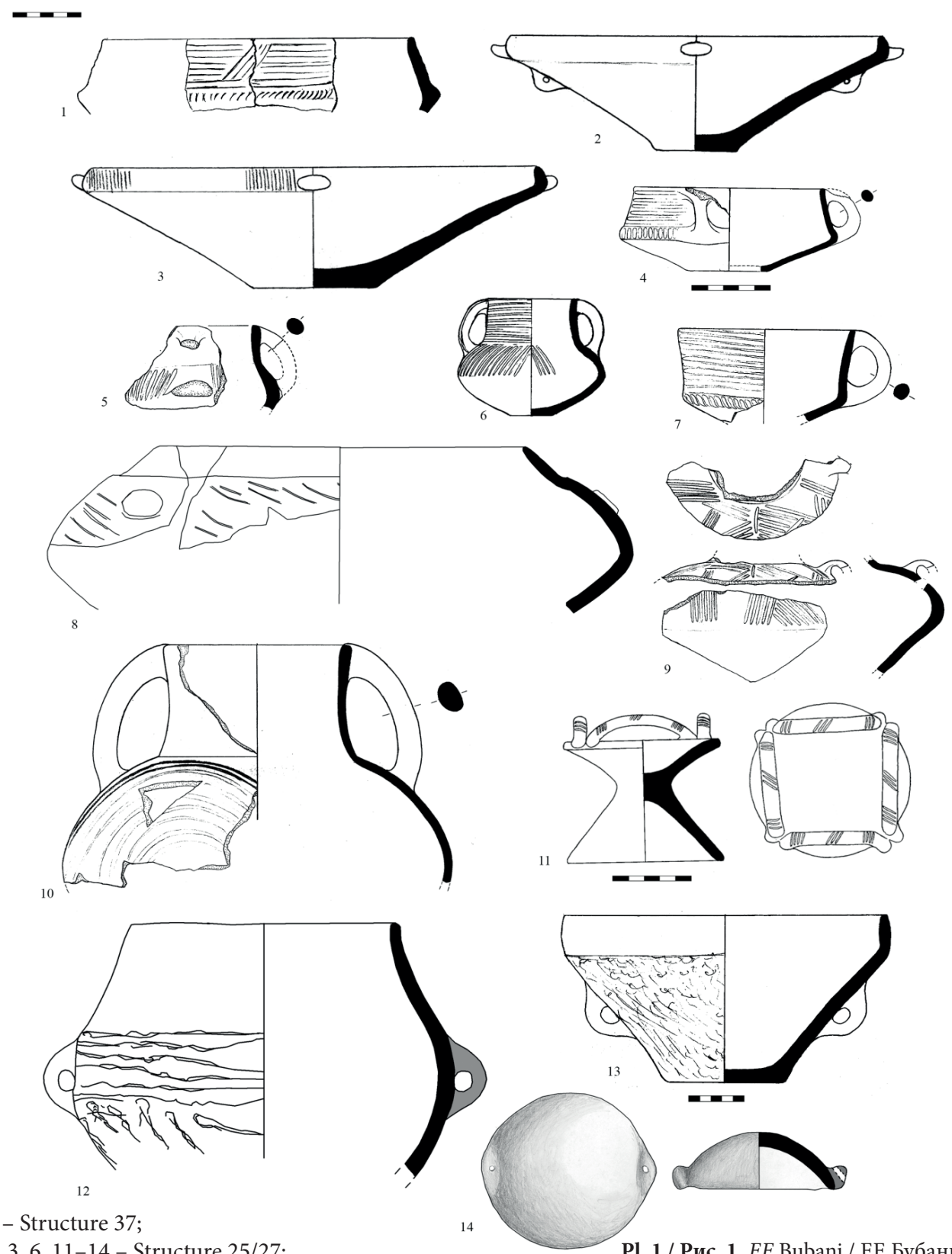

2, 3, 6, 11-14 - Structure 25/27;

P1. 1 / Рис. 1. EE Bubanj / ЕЕ Бубань

4, 5, 7, 9, 10 - Structure 69; 8 - Structure 26.

Источник: данные авторов

detected in Garašanin's trench I [47], some $10 \mathrm{~m}$ to the southeast of trench III from the 2013-2014 campaigns. The most common types of vessels and characteristic elements of Cernavoda III-Boleraz-Baden phenomenon are a conical or a semi-globular bowl with a funneled neck, sometimes decorated with channels and circular or oval impressions on the rim, globular vessels with short cylindrical or funneled necks (cups), with or without ribbon-like handles, lids or plates of the Bratislava type, semi-globular bowls with a slightly emphasized neck, handles with a segmented body and so on (pl. 3). 

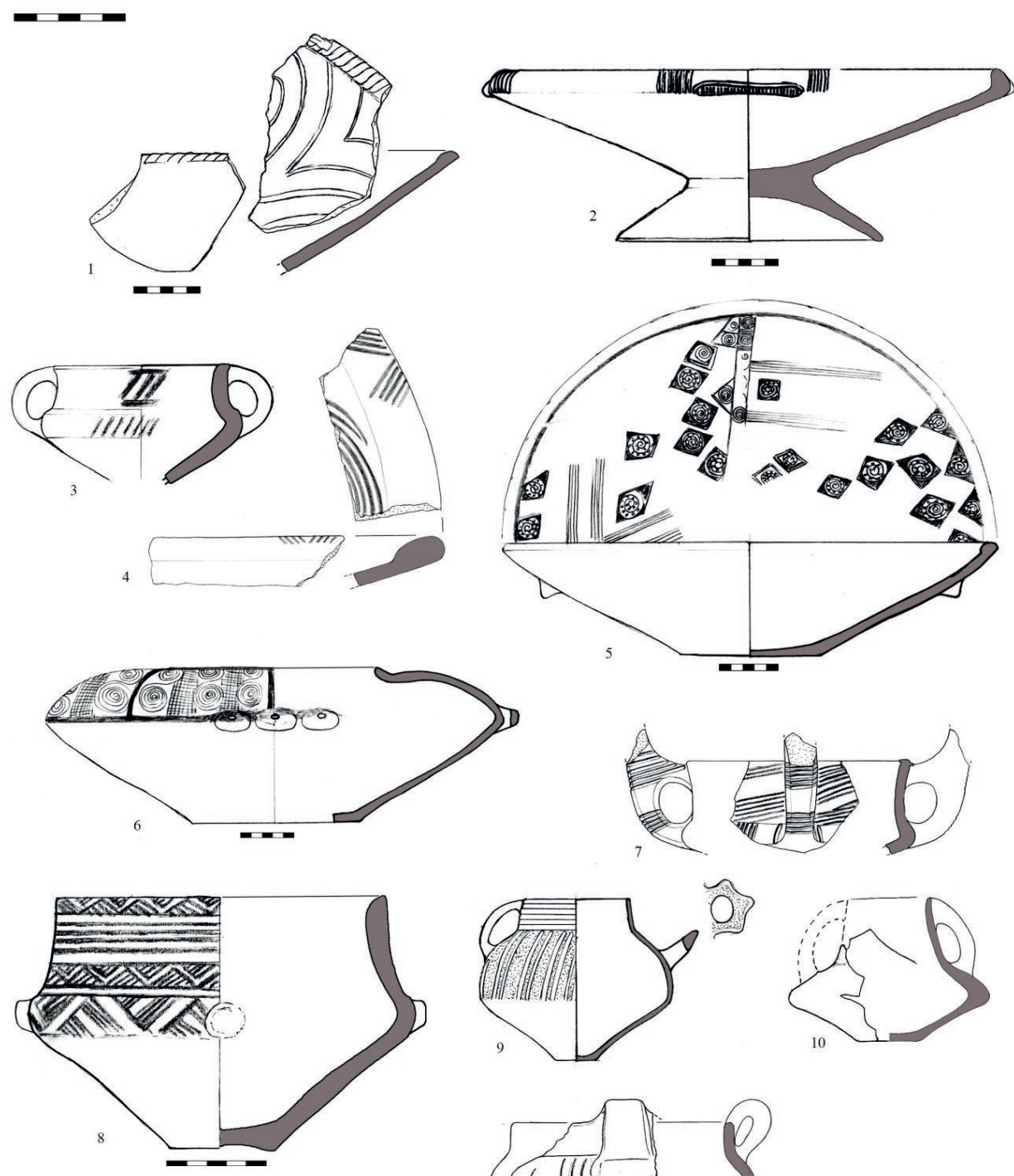

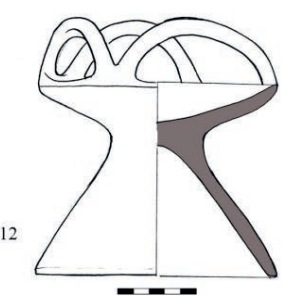

Pl. 2 / Puc. 2. EE Velika Humska Čuka Источник: данные авторов
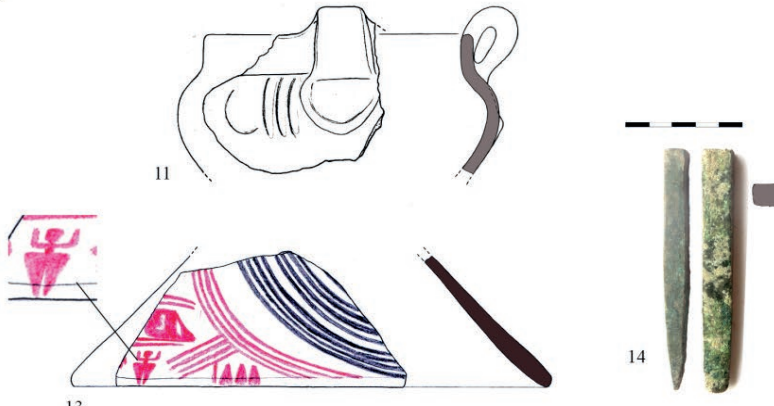

1 and $2-$ House 3, the earliest House floor $3,7,8$ and $14-$ House 2 4 and $10-$ House 1

5 and $6-$ House 3 , the latest horizon 9 and 11 - trench $1 / 18$, EE cultural layer 12 - House 4

13 - Structure 18 

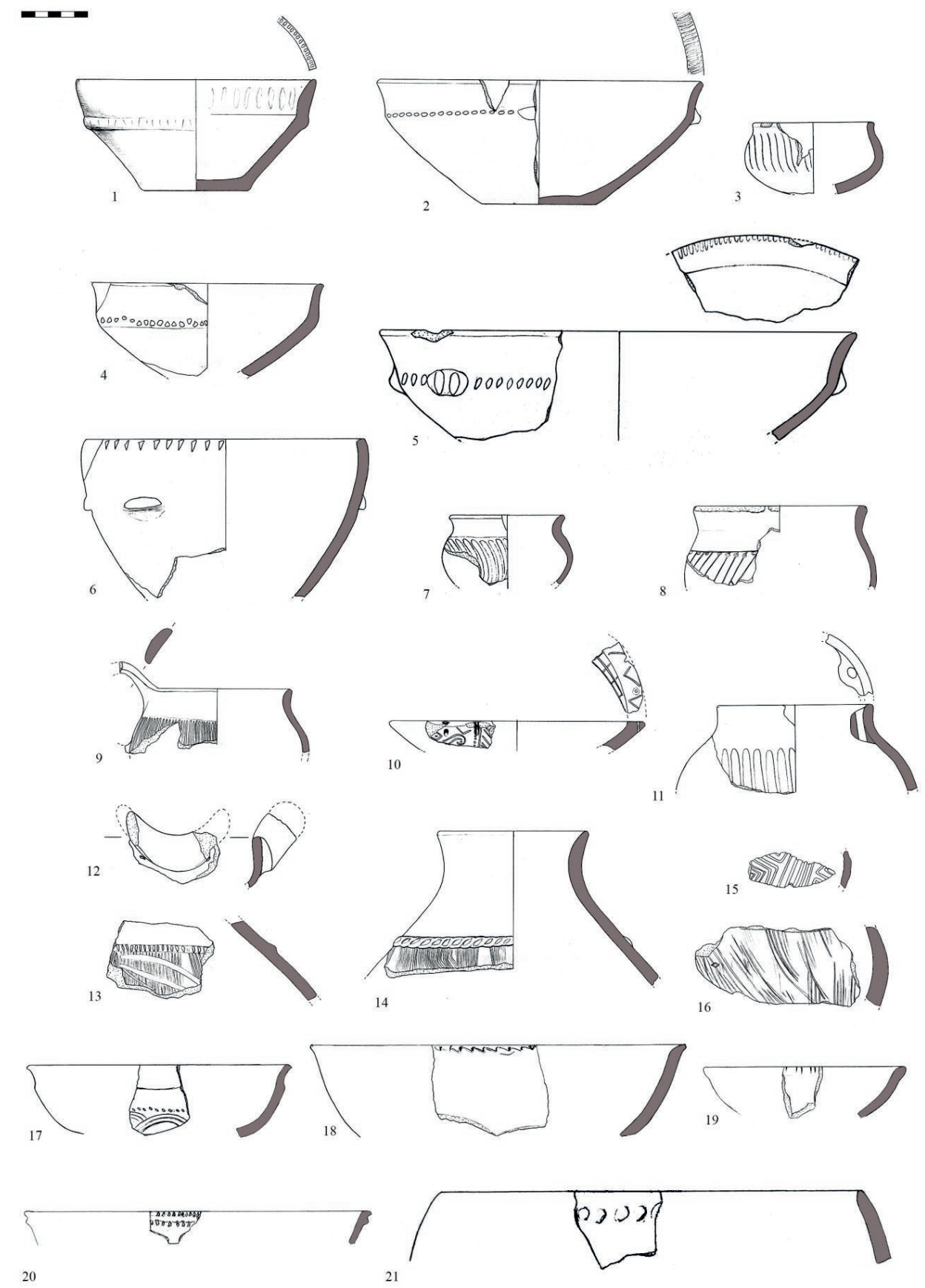

Pl. 3 / Pис. 3. ME - Bubanj / ME - Бубань Источник: данные авторов
1-16 - The earlier horison of the ČVIII-B-B phenomenon

17-21 - The later horison of the CYVIII-B-B phenomenon 
Table 1 / Таблица 1

Table of Eneolithic absolute dates and cultural horisons at the sites of Bubanj and Velika Humska Čuka / Таблица абсолютных дат энеолита и культурных горизонтов на стоянках Бубань и Велика Хумска Чука

\begin{tabular}{|c|c|c|c|c|c|c|}
\hline No & Site & Context & Lab Code & BP & Cal BC & Published \\
\hline 1 & $\begin{array}{c}\text { Velika } \\
\text { Humska } \\
\text { Čuka }\end{array}$ & $\begin{array}{l}\text { House } 3 \text { (the } \\
\text { oldest house } \\
\text { floor) }\end{array}$ & $\begin{array}{c}\mathrm{DeA} \\
21482\end{array}$ & $5571 \pm 39$ & $\begin{array}{c}4490-4340 \text { sigma } 2 \\
4447-4373(68 \% \\
\text { CalPal) }\end{array}$ & $\begin{array}{c}\text { Bulatović et al. } \\
2020\end{array}$ \\
\hline 2 & $\begin{array}{l}\text { Velika } \\
\text { Humska } \\
\text { Čuka }\end{array}$ & $\begin{array}{c}\text { Substruction } \\
\text { of the kiln } \\
\text { floor between } \\
\text { Houses } 1 \text { and } 3\end{array}$ & $\begin{array}{c}\text { DeA } \\
26775\end{array}$ & $5539 \pm 32$ & $\begin{array}{cl}4450-4340 & (95.4 \%) \\
4370-4345 & (47 \%) \\
4442-4421 & (37 \%)\end{array}$ & This study \\
\hline 3 & $\begin{array}{c}\text { Velika } \\
\text { Humska } \\
\text { Čuka }\end{array}$ & House 4 & $\begin{array}{c}\text { DeA } \\
21483\end{array}$ & 5481.40 & $\begin{array}{c}4450-4250 \text { sigma } 2 \\
4360-4282(68 \% \\
\text { CalPal) }\end{array}$ & $\begin{array}{c}\text { Bulatović et al. } \\
2020\end{array}$ \\
\hline 4 & $\begin{array}{l}\text { Velika } \\
\text { Humska } \\
\text { Čuka }\end{array}$ & House 2 & $\begin{array}{c}\text { AA } \\
109498\end{array}$ & $5473 \pm 31$ & $\begin{array}{l}4365-4259(95.4 \%) \\
4352-4326(51.0 \%)\end{array}$ & $\begin{array}{c}\text { Bulatović, } \\
\text { Vander Linden, } \\
\text { Gori } 2018 \\
\end{array}$ \\
\hline 5 & $\begin{array}{l}\text { Velika } \\
\text { Humska } \\
\text { Čuka }\end{array}$ & Structure 18 & $\begin{array}{c}\text { DeA } \\
26776\end{array}$ & $5469 \pm 32$ & $\begin{array}{ll}4370-4250 & (95.4 \%) \\
4349-4326 & (58,5 \%)\end{array}$ & This study \\
\hline 6 & Bubanj & $\begin{array}{l}\text { structure } 69 \\
\quad \text { (pit) }\end{array}$ & $\begin{array}{l}\text { SUERC } \\
50666\end{array}$ & $5452 \pm 28$ & $\begin{array}{l}4351-4257(95.4 \%) \\
4343-4266(68,2 \%)\end{array}$ & $\begin{array}{c}\text { Bulatović, } \\
\text { Vander Linden } \\
2017 \\
\end{array}$ \\
\hline 7 & Bubanj & $\begin{array}{l}\text { structure } 3 \\
\text { (remains of the } \\
\text { LE house) }\end{array}$ & $\begin{array}{l}\text { MAMS } \\
31460\end{array}$ & $5445 \pm 24$ & $\begin{array}{l}4344-4260(95.4 \%) \\
4291-4266(40.8 \%)\end{array}$ & $\begin{array}{c}\text { Bulatović, } \\
\text { Vander Linden, } \\
\text { Gori } 2018 \\
\end{array}$ \\
\hline 8 & Bubanj & $\begin{array}{l}\text { structure } 37 \\
\text { (pit) }\end{array}$ & $\begin{array}{l}\text { Lyon } \\
13690\end{array}$ & $5440 \pm 30$ & $4346-4246(95.4 \%)$ & $\begin{array}{c}\text { Bulatović, } \\
\text { Vander Linden, } \\
\text { Gori } 2018 \\
\end{array}$ \\
\hline 9 & Bubanj & 27 (pit) & $\begin{array}{l}\text { Lyon } \\
13689\end{array}$ & $5435 \pm 30$ & $4343-4245$ (95.4\%) & $\begin{array}{c}\text { Bulatović, } \\
\text { Vander Linden, } \\
\text { Gori } 2018 \\
\end{array}$ \\
\hline 10 & Bubanj & $\begin{array}{l}\text { structure } 69 \\
\quad \text { (pit) }\end{array}$ & $\begin{array}{l}\text { SUERC } \\
50670\end{array}$ & $5433 \pm 30$ & $\begin{array}{l}4342-4245(95.4 \%) \\
4336-4262(68.2 \%)\end{array}$ & $\begin{array}{c}\text { Bulatović, } \\
\text { Vander Linden } \\
2017 \\
\end{array}$ \\
\hline 11 & $\begin{array}{l}\text { Velika } \\
\text { Humska } \\
\text { Čuka }\end{array}$ & House 1 & $\begin{array}{c}\text { DeA } \\
26774\end{array}$ & $5416 \pm 38$ & $\begin{array}{ll}4350-4070 & (95.4 \%) \\
4348-4228 & (90.4 \%) \\
4304-4250 & (72.6 \%) \\
\end{array}$ & This study \\
\hline 12 & Bubanj & $\begin{array}{l}\text { structure } 20 \\
\text { (pit) }\end{array}$ & $\begin{array}{l}\text { MAMS } \\
31463\end{array}$ & $5087 \pm 25$ & $\begin{array}{l}3960-3800(95.4 \%) \\
3881-3800(61.8 \%)\end{array}$ & $\begin{array}{c}\text { Bulatović, } \\
\text { Vander Linden, } \\
\text { Gori } 2018 \\
\end{array}$ \\
\hline 13 & $\begin{array}{l}\text { Velika } \\
\text { Humska } \\
\text { Čuka }\end{array}$ & $\begin{array}{c}\text { House } 3 \text { (the } \\
\text { youngest house } \\
\text { floor) }\end{array}$ & $\begin{array}{l}\text { DeA- } \\
19350\end{array}$ & $5064 \pm 36$ & $\begin{array}{c}3960-3780(\text { sigma } 2) \\
3848-3801(42 \%)\end{array}$ & This study \\
\hline 14 & Bubanj & $\begin{array}{l}\text { structure } 23 \\
\quad \text { (pit) }\end{array}$ & $\begin{array}{l}\text { Lyon } \\
13228\end{array}$ & $4615 \pm 35$ & $\begin{array}{l}3517-3339(94.3 \%) \\
3517-3396(63.6 \%)\end{array}$ & $\begin{array}{c}\text { Bulatović, } \\
\text { Vander Linden } \\
2017\end{array}$ \\
\hline
\end{tabular}




\begin{tabular}{|c|c|c|c|c|c|c|}
\hline No & Site & Context & Lab Code & BP & Cal BC & Published \\
\hline 15 & Bubanj & $\begin{array}{l}\text { structure } 108 \\
\text { (pit) }\end{array}$ & $\begin{array}{l}\text { SUERC } \\
69295\end{array}$ & $4587 \pm 37$ & $\begin{array}{l}3502-3109(95.4 \%) \\
3495-3138(68.2 \%)\end{array}$ & $\begin{array}{c}\text { Bulatović, } \\
\text { Vander Linden } \\
2017\end{array}$ \\
\hline 16 & Bubanj & $\begin{array}{l}\text { structure 82A } \\
\text { (under the } \\
\text { floor) }\end{array}$ & $\begin{array}{l}\text { MAMS } \\
31462\end{array}$ & $4586 \pm 22$ & $\begin{array}{l}3493-3138(95.4 \%) \\
3481-3348(68.2 \%)\end{array}$ & $\begin{array}{l}\text { Bulatović, Gori, } \\
\text { Vander Linden } \\
2020\end{array}$ \\
\hline 17 & Bubanj & structure 54 & $\begin{array}{l}\text { SUERC } \\
50673\end{array}$ & $4529 \pm 32$ & $\begin{array}{l}3361-3102(95.4 \%) \\
3355-3117(68.2 \%)\end{array}$ & $\begin{array}{c}\text { Bulatović, } \\
\text { Vander Linden } \\
2017\end{array}$ \\
\hline 18 & Bubanj & $\begin{array}{c}\text { Trench 2/spit } \\
17\end{array}$ & $\begin{array}{l}\text { SUERC } \\
50672\end{array}$ & $4516 \pm 32$ & $\begin{array}{l}3356-3098(95.4 \%) \\
3347-3115(68.2 \%)\end{array}$ & $\begin{array}{c}\text { Bulatović, } \\
\text { Vander Linden } \\
2017\end{array}$ \\
\hline 19 & Bubanj & $\begin{array}{c}\text { structure } 49 / 93 \\
\text { (remains of a } \\
\text { house) }\end{array}$ & $\begin{array}{l}\text { MAMS } \\
31466\end{array}$ & $4494 \pm 24$ & $\begin{array}{l}3339-3098(95.4 \%) \\
3331-3105(68.2 \%)\end{array}$ & $\begin{array}{c}\text { Bulatović, Gori, } \\
\text { Vander Linden } \\
2020\end{array}$ \\
\hline 20 & Bubanj & structure 42 & $\begin{array}{c}\text { MAMS } \\
31465\end{array}$ & $4481 \pm 23$ & $\begin{array}{l}3338-3037(95.4 \%) \\
3327-3099(68.2 \%)\end{array}$ & $\begin{array}{c}\text { Bulatović, Gori, } \\
\text { Vander Linden } \\
2020\end{array}$ \\
\hline 21 & Bubanj & $\begin{array}{c}\text { structure } 15 \\
\text { (remains of the } \\
\text { house) }\end{array}$ & $\begin{array}{l}\text { SUERC } \\
69296\end{array}$ & $4470 \pm 37$ & $\begin{array}{l}3341-3024(95.4 \%) \\
3330-3037(68.2 \%)\end{array}$ & $\begin{array}{c}\text { Bulatović, } \\
\text { Vander Linden } \\
2017\end{array}$ \\
\hline 22 & Bubanj & $\begin{array}{l}\text { structure } 83 \\
\text { (remains of a } \\
\text { house) }\end{array}$ & $\begin{array}{l}\text { MAMS } \\
31458\end{array}$ & $4400 \pm 25$ & $\begin{array}{l}3092-2925(95.4 \%) \\
3086-2933(68.2 \%)\end{array}$ & $\begin{array}{c}\text { Bulatović, Gori, } \\
\text { Vander Linden } \\
2020\end{array}$ \\
\hline 23 & Bubanj & $\begin{array}{c}\text { structure } 15 / 2 \\
\text { (remains of a } \\
\text { house) }\end{array}$ & $\begin{array}{l}\text { MAMS } \\
31459\end{array}$ & $4398 \pm 23$ & $\begin{array}{l}3090-2925(95.4 \%) \\
3084-2932(68.2 \%)\end{array}$ & $\begin{array}{l}\text { Bulatović, Gori, } \\
\text { Vander Linden } \\
2020\end{array}$ \\
\hline 24 & Bubanj & $\begin{array}{l}\text { structure } 3 \\
\text { (remains of a } \\
\text { house) }\end{array}$ & $\begin{array}{l}\text { SUERC } \\
69297\end{array}$ & $4393 \pm 35$ & $\begin{array}{l}3101-2910(95.4 \%) \\
3083-2928(68.2 \%)\end{array}$ & $\begin{array}{c}\text { Bulatović, } \\
\text { Vander Linden } \\
2017\end{array}$ \\
\hline 25 & Bubanj & structure 40 & $\begin{array}{l}\text { MAMS } \\
31464\end{array}$ & $4289 \pm 23$ & $\begin{array}{l}2919-2885(95.4 \%) \\
2909-2893(68.2 \%)\end{array}$ & $\begin{array}{c}\text { Bulatović, Gori, } \\
\text { Vander Linden } \\
2020 \\
\end{array}$ \\
\hline 26 & $\begin{array}{l}\text { Velika } \\
\text { Humska } \\
\text { Čuka }\end{array}$ & $\begin{array}{c}\text { structure 6A } \\
\text { (remains of a } \\
\text { house) }\end{array}$ & $\begin{array}{l}\text { MAMS } \\
31475\end{array}$ & $4103 \pm 16$ & $\begin{array}{l}2851-2579(95.4 \%) \\
2835-2587(68.2 \%)\end{array}$ & $\begin{array}{c}\text { Bulatović, Gori, } \\
\text { Vander Linden } \\
2020\end{array}$ \\
\hline
\end{tabular}

Источник: составлено авторами

Besides the mentioned finds, a figurine of the Kopflose type, a zoomorphic figurine, as well as numerous loom weights, weights, spoons, chipped and ground stone tools, and other finds that testify the life of those communities at the site of Bubanj during the Middle Eneolithic were recorded.

Several absolute dates originating from enclosed features and one from the cultural layer indicated that the settlements within the cultural layer III with two horisons (Middle Eneolithic) existed in a period between 3517 and 3098 cal BCE (probability of 95.4\%) or be- 
tween 3517 and 3115 cal BCE (probability of 68.2\%) (tab. 1/14-18) [38].

\section{Late Eneolithic}

(ca. 3200/3100-2800/2700 cal BCE)

According to the stratigraphy and the enclosed features registered during the excavations at the site of Bubanj, within the cultural layer comprised of ashy grey soil, which is attributed to the Late Eneolithic (cultural layer IV), a total of three habitation horisons have been separated (marked I to III, from the earliest to the youngest), with finds attributed to the Coțofeni-Kostolac group (cf. $[3 ; 49 ; 50 ; 51 ; 52])$. A slightly different layer of light-brown soil (layer V) with finds attributed to the final phase of the Late Eneolithic or the Bubanj-Hum II group, was registered above it [37].

The enclosed features of layer IV are represented by house remains, oven floors, various pits, walking surfaces, etc. The layer could be correlated with horisons II and IIa defined by $M$. Garašanin during the excavations in the 50s of the last century $[35 ; 36]$.

The most prominent features from this layer are the remains of two houses with rectangular layout, oriented approximately north-south, with the width of 3-3.5 $\mathrm{m}$ and unknown length. Both houses originate from the earliest horison. The western house most likely had an apsidal northern wall, which is an architectural feature already noted in contemporary houses in the territory of Pannonia [52]. The houses are parallel and the gap between them measures 1.5-2 $\mathrm{m}$, while a walking surfaces was recorded surrounding the houses. Judging by numerous post holes, finds of daub, and the vast amount of ash within the layer, the houses were most likely built in the wattle and daub technique, with an abundance of timber. Two hearths were located around 1-2 $\mathrm{m}$ west of the eastern house, and an oven was recorded approximately $2 \mathrm{~m}$ east of the houses.

The western, apsidal house, was renewed within the second horison and judging by the remains of floors to the east, it is possible that the eastern house was likewise renewed in this horison. The remains of floors made of stamped and burnt soil have also been recorded western of the apsidal house, which opens the possibility that the settlement was more densely inhabited during this horison compared to the previous.

Remains of floors of at least two rectangular houses, with the width of $2.5-3.5 \mathrm{~m}$ and unknown length, with the remains of oven floors and numerous surrounding pits, have also been recorded within the third horison.

Unfortunately, this remaining part of the site that was excavated in a period between 2008 and 2014 was quite narrow and intersected with various recent digs and graves, which significantly complicated the excavations, stratigraphy, and settlement structure distribution analysis. Despite that, one can note that this part of the eastern plateau was most densely settled during the Late Eneolithic period, which is confirmed by the results of Garašanin's excavationsin Trench I on the eastern plateau.

According to the stylistic and typological characteristics of the pottery, this cultural layer (layer IV) undoubtedly belonged to the bearers of the Coțofeni-Kostolac culture, which was widespread in the territory of eastern, central, and southeastern Serbia. The elements characteristic for the Coțofeni culture are semi-globular bowls with a slanted rim decorated with incised ornaments, deep semi-globular vessels decorated with vertical modeled ribs, amphorae with an emphasized and thickened rim, barrel-shaped pots with tongue-shaped handles, decorated with bands with finger impressions, the combed ornament, cross-cutting incised lines that form lozenges, the herringbone motif, lensshaped applications, corded ornament and so on (pl. 4/4, 7-9, 18, 20). In addition, the elements of pottery characteristic for the Kostolac culture such as the slightly S-profiled bowls with a funneled neck, amphorae with a narrow opening and widened belly (the socalled Fischbutte), and semi-globular cups, as well as decoration such as the Furchenstich ornament and rows of dotted notches forming various ornaments (parallel lines, zigzag 


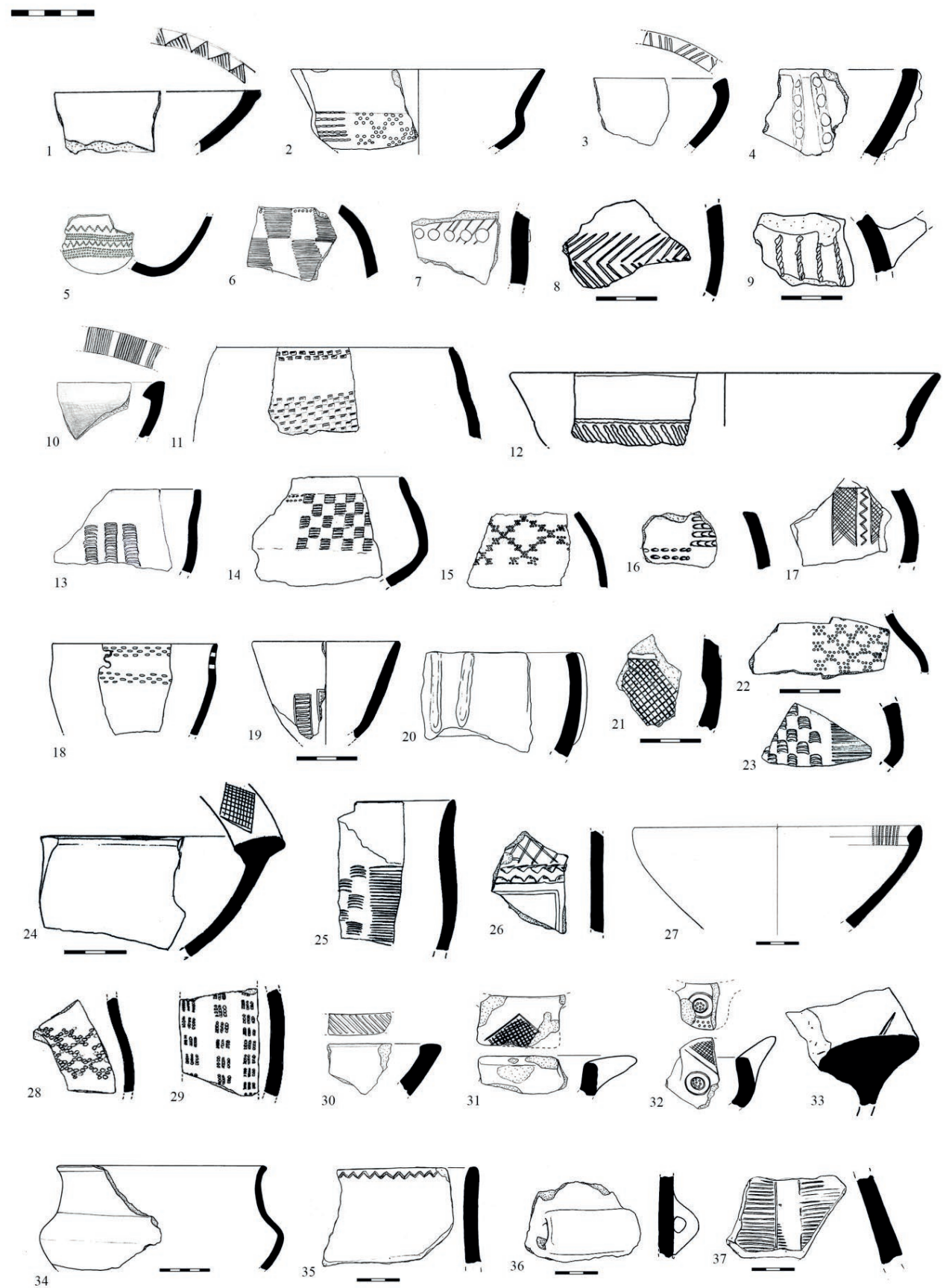

Pl. 4 / Pис. 4. LE - Bubanj and Velika Humska Čuka / $\mathrm{LE}$ - Бубань и Велика Хумска Чука

1-9 - Bubanj, the first horison of the LE 10-17 - Bubanj, the second horison of the LE Источник: данные авторов 18-23 - Bubanj, the third horison of the LE 24-26 - Bubanj, layer V 27-29 - Velika Humska Čuka, LE cultural layer 30-37 - Velika Humska Čuka, structure 6A (house remains from the final phase of the LE) 
lines, etc.) were also recorded in this layer (pl. 4/1-3, 5, 10-12, 15, 16, 22) (cf. [50; 51]). It has to be noted that certain elements such as vertical rows of densely incised horizontal or slightly arched parallel lines, or the ornament composed of geometrical shapes filled with a dense net comprised of cross-hatched incised lines, were recorded in both the second and especially the third horison (pl. 4/6, $13,14,17,19,21,23)$. Such elements are uncommon for this culture in the north, and could, therefore, be characterized as local elements. It has also been noted that starting from the second horison, the elements of the Kostolac culture are represented to a higher degree than the elements of the Coțofeni culture. On the other hand, both in the second and especially in the third horison, elements resembling the Vučedol culture sporadically occur. The ceramic inventory includes almost none of the forms characteristic for the previous period, while inherited decoration does prevail to a slightly higher degree.

Several absolute dates originating both from the enclosed features and cultural layer IV, revised based on the well-defined stratigraphy, chronologically determine the layer as belonging to the period between the second half of the $34^{\text {th }}$ century and the beginning of the $29^{\text {th }}$ century cal BCE. According to more precise absolute dates, the beginning of the earliest horison falls within $3339 \mathrm{cal}$ BCE (95.4\%), or $3331(68.2 \%)$, and the end of the youngesthorizon III is dated to 2885 $(95,4 \%)$, or $2893 \mathrm{cal} \mathrm{BCE} \mathrm{(68.4 \% )} \mathrm{(tab.} \mathrm{1/19-}$ 25) (cf. [40, p. 1173-1174].

In the layer of light-brown soil above cultural layer IV (layer V), remains of a rectangular house oriented northwest-southeast, of undefined dimensions, have been recorded, as well as one pit and two zones comprised of pebbles and potsherds. The ceramic finds from this layer correspond to the Bubanj-Hum II cultural group, defined by M. Garašanin more than half a century ago, yet only recently scientifically affirmed. The basic ceramic forms of the aforementioned group at the site of Bubanj are semi-globular bowls with T-shaped rims, bowls with in- verted rims, bowls with rectangular modeled extensions on the rim, and the favored ornamental motifs are incised hatched lines, rows of parallel incised short lines (pl. 4/2425), while deep incising characteristic for the Vučedol group is sporadic (pl. 4/26). No absolute dates are acquired for this layer at the site of Bubanj. The group is more precisely culturally and chronologically defined by finds from the site of Velika Humska Čuka, which will be further elaborated.

\section{The chronology and the settlement character during the Eneolithic at the site of Velika Humska Čuka}

\section{Early Eneolithic \\ (ca. 4500/4400-3800/3700 cal BCE)}

The earliest layer with the remains of the Early Eneolithic above-ground structures with a depth of up to $0.7 \mathrm{~m}$ is the best-preserved layer at the site. The excavations in 2009 yielded ceramic vessels bearing stylistic and typological characteristics that indicated the existance of an older (graphite painted pottery) and younger phase of the Early Eneolithic (the so-called Scheibenhenkel horison or Galatin-Sălcuța IV-Teliš IV-Herculane II-II horison) [43]. The younger phase was not separated by M. Garašanin during his excavations, yet variously graphite decorated pottery was recorded in the central portion of the site during the 1954-1956 campaigns [42]. No residential structures were recorded on that occasion.

The latest research between 2014 and 2021 yielded features comprised of remains of above-ground houses and accompanying working surfaces with a large number of ceramic weights, oven floors, hearths, and pits within the Early Eneolithic layer. Of particular importance is the discovery of a portion of a settlement with four excavated rectangular above-ground structures with a considerable amount of finds, especially completely preserved and fragmented vessels decorated with graphite, which contrast a relatively scarce representation of such vessels at the site of Bubanj. Likewise, the latest 
research has pointed out that the residential structures from this period are concentrated in the eastern portion of the site, that those are smaller in dimensions (approximately $5 \times 3.5 \mathrm{~m}$ ) and rectangular, oriented northsouth with a slight deviation, built in wattle and daub technique and burnt. Three of the houses (1-3) were used for a longer period, renewed several times, which is indicated by numerous floors layered one above the other, with the thickness of up to $0.4 \mathrm{~m}$ in total, portable finds, as well as absolute dates. The houses contained a significant number of ceramic vessels and other finds, and in one of the houses (House 3), besides several vessels laid into pits dug into the house floor, fragments of two ceramic drums, the so-called tarabouki were recorded, which indicate that music and dancing were significant activities at the site. This is further supported with a find of a beaker foot with a painted representation of a woman in motion with raised hands (dance or adoration stance) (pl. 2/13), which was recorded next to the oven in the proximity of House 3. A rectangular altar painted in various colors was recorded within the same house, which indicates that certain rituals took place within the settlement. A find of a copper chisel (pl. 2/14), typologically similar to the examples from the Pločnik hoards, and the radiometric analysis of an animal bone found in the vicinity of the chisel, indicate that this portion of the site is either synchronous or in close chronological relations with the youngest horison at the site of Pločnik which is characterized by metallurgical activities. Numerous finds of chipped stone objects in all phases of production at the site indicate that the Kremenac deposits represented a significant economic resource of the community that exploited it. The layer is primarily represented by medium and coarse ware vessels tempered with sand and small stones, with slightly burnished or rough surfaces, baked in brown, reddish, or grey. The fine ware vessels tempered with sand, with burnished surfaces, baked in black and brown are dominated by forms such as beakers with arched handles oval in cross-section (pl. 2/3, $7,9,10$ ), bowls with inverted rims, often with large hollow foot (pl. 2/2), conical bowls and plates with thickened rims (pl. 2/1, 4, 5) and deep biconical bowls with a conical and rarely funneled neck (pl. 2/8). Save for the mentioned forms, lavishly decorated vessels with a narrow neck and a wide belly are recorded to a lesser degree (pl. 2/6). In general, the ornamental techniques are represented by incising (pl. 2/1), pricking (pl. 2/9), channeling (pl. 2/1. 2, 9, 11), graphite and pasty color paining (red, white, yellow, purple) (pl. 2/3-8, 13). A golden coating is recorded on two potsherds from House 3 , which indicates either the mastering of this technique in the settlement (at least within the latest horisonto which the potsherds are dated) or contacts with communities that were already acquainted with the technique. ${ }^{1}$ Particularly interesting are vessels (beakers) on high hollow foot, with arched handles which surpass the mouth of the vessel (pl. 2/2), and often intersect, sometimes with an anthropomorphic figure at the top. Such vessels are extremely rare and appear almost exclusively at the sites of Bubanj and Velika Humska Čuka, especially the latter, and could be interpreted as a local autochthonous ceramic form.

According to the stratigraphy and absolute dates, at least three settlements (horisons) can be observed at the site during the Early Eneolithic. The first horison is represented by house 3 (earliest habitation horison) $(\mathrm{pl} .2 / 1,2)$ and the remains of the oven between houses 1 and 3 , while the second horison is represented by Houses 1 (pl. 2/4, 10), 2 (pl. 2/3, 7, 8, 14) and 4 (pl. 2/12), as well as the group of potsherds and bones with the aforementioned vessel painted with a woman in motion (pl. 2/13). The youngest, third horison, is represented by the youngest floor in House 3, probably with pits and lavishly decorated pottery (pl. 2/5-6), tarabouki, and a massive altar. The horison is also characterized by vessels with handles with wid-

\footnotetext{
The analyses were conducted by the Laboratory of the Institute for the Protection of Cultural Monuments of Serbia - Belgrade.
} 
ened plate-shaped roots (the Scheinbenhenkel type) and globular beakers decorated with narrow intertwined channels and small punctures (pl. 2/9). The absolute dates position the first horison in the $45^{\text {th }}-44^{\text {th }}$ century BCE (tab. 1/1, 2), the second horison into the $44^{\text {th }}-43^{\text {rd }}$ century BCE (tab. $1 / 3-5,11$ ), and the third horison into the $40^{\text {th }}-39^{\text {th }}$ century BCE (tab. 1/13), (tab. 1/1-5, 11, 13).

\section{Late Eneolithic}

\section{(ca. 3200/3100-2800/2700 cal BCE)}

No finds or cultural layers attributed to the Middle Eneolithic, meaning Cernavodă III-Boleraz or Baden cultural groups have been recorded at the site of Velika Humska Čuka, save for one enclosed feature, most likely a house, as well as finds which are attributed to the final phase of the Late Eneolithic.

Layers from the Early and Late Eneolithic, all phases of the Bronze Age up to the Late Iron Age have been recorded at the site of Velika Humska Čuka. Unfortunately, such vertical stratigraphy on a relatively small depth of cultural layer, between 0.7 and $2 \mathrm{~m}$, caused poor preservation of all of the layers, including the Late Eneolithic layer. Fortunately, during the 2016 campaign, remains of a structure represented by a zone of stamped and partially burnt soil of approximately rectangular shape were recorded. The structure was laid directly on the rock and penetrated two cross-sections of the trench, which disabled the precise determination of its dimensions. This zone contained exclusively pottery attributed to the final phase of the Eneolithic, the Bubanj-Hum II group. The pottery is represented by bowls with inverted rims and modeled rectangular extensions, mostly decorated with stamps, net motif and incised lines (pl.4/31, 32), bowls with Tshaped rims (pl. 4/33), and biconical bowls with an emphasized profile which resemble the Vučedol «terina» (pl. 4/34). Some of the elements on pottery are known from the preceding period of the Coțofeni-Kostolac group, such as bowls with widened rim and decorated upper surface (pl. 4/30), large ves- sels with a long cylindrical neck decorated with a zigzag line below the rim (pl. 4/35), tunneled handles (pl. 4/36) and ornamental motifs comprised of vertical rows of parallel horizontally incised lines (pl. 4/37), which have also been registered at the site of Bubanj in layers IV and V (pl. 4/6, 13, 14, etc.). The absolute dates from the structure position it into the period between 2851 and $2579 \mathrm{cal}$ BCE (probability 95.4\%), that is 2835 and 2587 cal BCE (68.2\% probability), meaning the period between the end of the $29^{\text {th }}$ and the beginning of the $26^{\text {th }}$ century [40].

Other finds with elements of the Late Eneolithic have also been registered at the site of Velika Humska Čuka (pl.4/27-29), although mostly without a proper context or absolute dates. Therefore, it remains unclear if those finds are to be attributed to the Coțofeni-Kostolac group or if that horison is present at the site, or those finds represent the survival within the Bubanj-Hum II group, whose existence at the site is argued by an enclosed context and absolute date.

\section{Discussion}

The site of Bubanj is positioned on a plateau of an elevation within a lowland environment on fluvial sediments (altitude of $198 \mathrm{~m}$, elevation of $15 \mathrm{~m}$ ), within the contact zone of alluvial plain and river terrace, in the vicinity of the confluence zone of Nišava and South Morava rivers. The site in Hum is distanced from fluvial formations and located deep within the hinterland at a dominant elevation (altitude of $455 \mathrm{~m}$, elevation $120 \mathrm{~m}$ ) within the contact zone of Neogenic sediments and hilly-mountainous hinterland. It lies $8.5 \mathrm{~km}$ northeast of Bubanj, while flint deposits at the Kremenac location, which are considered as an important mine exploited during prehistory, lie approximately $2.1 \mathrm{~km}$ to the west. Copper deposits have been recorded around $8.3 \mathrm{~km}$ to the northeast. The visual communication with the site of Bubanj and the Kremenac deposits indicates their importance and mutual connections.

Significant surfaces covered with alluvial soils, suitable for agriculture and animal hus- 
bandry have been recorded in the vicinity of the site of Bubanj, as well as three toponyms that indicate saline soils and saltwater springs. The surroundings of the site of Velika Humska Čuka are dominated by meadow vegetation (vertisol) and forest soil types, as well as one toponym which indicates a surface with saline soils. In terms of geology and pedology, the site is located within an ecosystem quite suitable for the development of meadow biocenosis with pastures and forests, meaning a landscape rather suitable for animal husbandry than agriculture. A small area covered with eutric cambisol, a soil type which could according to its physical and chemical properties be utilized for agriculture, is located on the southern side of the site. However, most of the soil types represented in the surroundings of the site, formed on calcareous sediments, are unsuitable for cereal cultivation even in modern conditions, and therefore the region of Hum is even nowadays favorable for viticulture and animal husbandry, primary sheep and goats, rather than for agriculture.

Considering the character of the portion of the settlement excavated between 2008 and 2014 and the position of the site of Bubanj, within the central part of the lowland landscape, which is equally well connected with communications leading to the south and north through the South Morava Valley, to the east through the Nišava Valley and to the west through the Toplica Valley, it can be considered that the site had a function of a regional communication hub with an important role of agriculture and animal husbandry and an important place for the production of textiles and utilitarian object made of leather and fur, exchange and trade. The site in Hum was formed in the hinterland, distanced from river valleys rich in fertile alluvial soil types and in the vicinity of mineral resources, which indicates higher importance of animal husbandry, hunting, and organized supplying with copper and flint. The spatial proximity between the site of Bubanj and the site of Velika Humska Čuka, which had a visual control over a vast area of the course of South Morava, as well as their favorable mutual visual communication (fig. 4), confirms that both sites represented important spots for inhabitation, places for the control of the surrounding resources, main communication and the flow of resources and information. The complementarity in therms of soil resources, surrounding flora and fauna and topographic and geomorphological characteristics, the wealth in flint and to a lesser degree copper tools, recorded within the Eneolithic layers on both sites, as well as visual control of the site in Hum over the neighboring quality flint and copper deposits, firmly indicate that those settlements were economically cooperative and tightly connected, at least at one point, the period of $44^{\text {th }} / 43^{\text {rd }}$ century BCE, as confirmed by absolute dates. Additionally, finds of tarabouki at the site of Velika Humska Čuka point out that the sites could have also mutually communicated with sound. Similarly, finds of carbonized pinewood within the Early Eneolithic contexts at the site of Bubanj [53], suggest that the wood was acquired from locations at higher altitudes, such as the surroundings of the site of Velika Humska Čuka.

Significant changes in settlement patterns occur during the Early Eneolithic of the Central Balkans. The site of Bubanj was uninhabited during the Late Neolithic, and the first habitation following the Starčevo settlement is connected with the second half of the $5^{\text {th }}$ millennium BCE. The site of Velika Humska Čuka was inhabited for the first time during the Early Eneolithic, and similarly to the site of Bubanj, remains an often inhabited location during the younger phases of prehistory. Small excavated surfaces, compared to the overall sizes of those sites, suggest that certain horisons have been less represented and noted, which has been partially confirmed by the latest archaeological excavations and radiometric measurements. The assumption that the sites of Bubanj and Velika Humska Čuka were simultaneously inhabited during the Early Eneolithic [43], between 4350 and $4250 \mathrm{BC}$, is now con- 


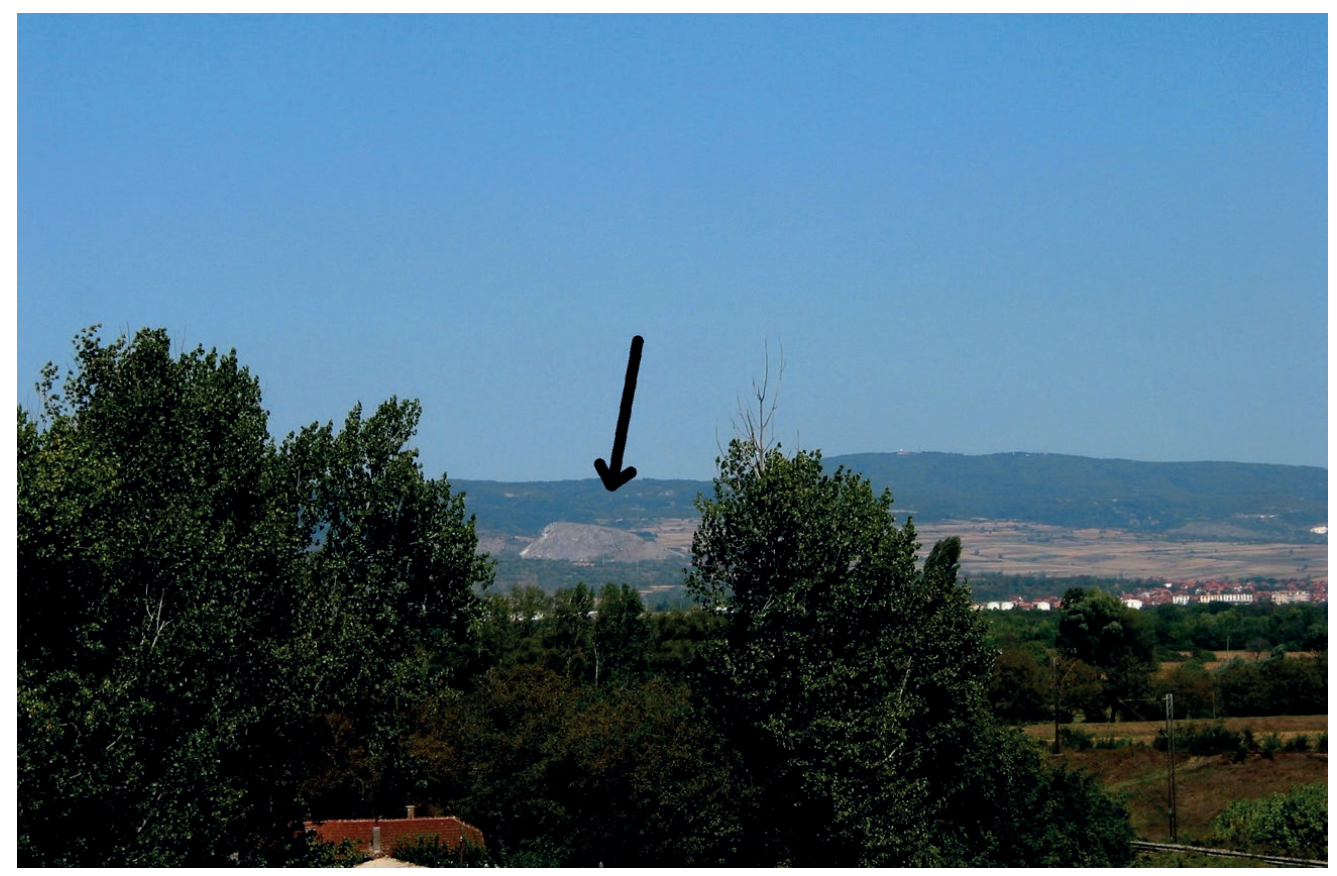

Fig. 4 / Рис. 4. View on Velika Humska Čuka from the site of Bubanj / Вид на Велика Хумска Чука с городища Бубань

Источник: фото авторов

firmed. Therefore, it is possible that during the summer, glades surrounding Hum were utilized for livestock grazing and hunting, prospection, collection and possible mining of flint, and even copper, while during the winter, the herds were taken to lowland settlement (Bubanj), where the agriculture represented a dominant economic activity. Continuous similarities in stylistic and typological characteristics of pottery between Bubanj and Velika Humska Čuka (Early, Middle, and Late Eneolithic and Bronze Age) speak in favor of it.

Similarly, it is possible that the site in Hum was utilized as an alternative and temporary settlement in certain periods, when climate oscillations, migrations, conflicts, and/or other factors could have significantly affected the life of prehistoric populations within this micro-region. The higher social mobility is indicated by archaeozoological analysis on these two sites, which pointed out the appearance of a new type of stockbreeding during the Early Eneolithic, which is likewise recorded during the Middle and Late Eneolithic ${ }^{1}$. Such a trend is represented by higher dependence on ovicaprines compared to the Late Neolithic [54], a higher degree of diversification and specialization regarding the animal management strategies, meaning that certain settlements were highly focused on ovicaprines, and others on the cattle breeding, pig breeding or hunting [55]. The pedological analysis of the Late Neolithic and Early Eneolithic sites in the Central Balkans suggested the increased spectrum of available soil types surrounding the Early Eneolithic settlements and an overall higher orientation of settlements towards those soils unsuitable for agriculture, as well as the complete lack of groups of settlements focused solely towards fertile forest soils, which are characteristic for the Vinča culture [13]. However, it is important to high-

\footnotetext{
Bulatović J. Arheozoološki aspekti društvenih i kulturnih promena na centralnom Balkanu u petom milenijumu pre nove ere. Unpublished $\mathrm{PhD}$ thesis. Belgrade, 2018, p. 238.
} 
light that the decline in the importance of agriculture in certain settlements is followed by relatively numerous groups of settlements characterized by highly suitable conditions for various agricultural strategies [13]. The research of topographic characteristics of sites suggests a more frequent settling of topographically limited and naturally fortified elevated plateaus and hidden caves in the hinterland, which were often concurrent with adjacent settlements in lowlands ${ }^{1}$ [12]. Additionally, the research indicated diversification, specialisation, and integration of local settlements and most likely groups of settlements in the neighboring micro-regions ${ }^{2}$ [13]. Further, the regional spatial distribution of settlements points out the process of abandonment of large and long-lasting Vinča settlements and the formation of small dispersed settlement on completely new locations, abandonment or scarce inhabitance of previously densely settled micro-regions, and the tendency to group settlements in the ore-bearing micro-regions of eastern Serbia [13].

According to the latest radiometric measurement of the youngest habitation horisons of large Vinča settlements, the abandonment process occurred in a period between $4700 / 4650$ and $4400 / 4350 \mathrm{cal} \mathrm{BCE}^{3}$. The process is followed by an increase in the number of settlements on plateaus of dominant elevations, which are naturally fortified, continuity in the construction of ditches and palisades, and frequent burnt settling horisons within the Late Vinča and BSK cultural complex settlements. The process was gradual and of uneven duration in different

\footnotetext{
Milanović D. The interply between lowland and highland zones: Engaging the landscape of eastern Serbia and western Bulgaria in the second half of the 5th millennium BCE. In: Gori M., Hellmuth-Kramberger A., Krapf T., Recchia G.,eds. Archaeology of Mountainous Landscapes in Balkan Prehistory. Universitätsforschungen zur prähistorischen Archäologie, Rudolf Habelt, Bonn (готовится к печати в 2022 г.).

3 Milanović D. The Copper Age in the Central Balkans. In: Parkinson W. A., Gyucha A., Galaty M.,eds. Oxford Handbook of Balkan Prehistory. Oxford, Oxford University Press (готовится к печати в 2022 г.).
}

micro-regions of the Central Balkans, and the abundance of sites on naturally fortified elevations and additional enclosing indicate that the process was accompanied by smaller or greater conflicts. The earliest BSK settlements, which were significantly smaller than the Late Vinča settlements and have already embraced innovations in various economic and social aspects, appear during that period. Such settlements were often founded on dominant and naturally fortified elevations, such as Velika Humska Čuka, which reaffirms previous assumptions on their partially concurrent existence and the violent end of life in numerous Vinča settlements.

Therefore, the absolute dates indicate that the settlement at the site of Velika Humska Čuka was formed a century before the settlement at the site of Bubanj, already in the $45^{\text {th }} / 44^{\text {th }}$ century BCE, which supports the idea that the earliest BSK settlements in the Central Balkans were formed on naturally fortified elevations and additionally fortified. During the $44^{\text {th }} / 43^{\text {rd }}$ century BCE, settlements existed on both sites and probably formed some sort of coexistence. Yet, according to the existing data, the settlement at the site of Bubanj ceases to exist at the end of the $5^{\text {th }}$ millennium $\mathrm{BCE}$, or at least the settling becomes less intensive, contrary to Velika Humska Čuka, where life continues undisturbed. There is an absolute date from that period from the site of Bubanj, although the sample (shell valve) is insecure since it originates from a younger feature that damaged the Early Eneolithic layer, and therefore it remains unclear whether the location of the sample is the result of human or animal activity. The portable finds whose stylistic and typological characteristics would be securely attributed to this period are lacking, save for several potsherds whose stylistic elements could indicate the latest phase of the Early Eneolithic.

On the other hand, the site of Velika Humska Čuka yielded numerous finds of vessels with the so-called Scheibenhenkel handles, characteristic for the Sălcuț IV or Galatin groups (ornament formed of hatched 
summary incised lines, rows of crescent nail impressions, beakers decorated with narrow and densely positioned channels combined with punctuation, vessels on high foot with small tunneled handles on the junction of foot and the recipient, etc.) [56;57;58], which points to an active inhabitation of the site during this period. Likewise, the youngest horison of house 3 is dated to this period, with pits filled with lavishly decorated and multicolored painted vessels, including the golden coating, tarabouki, altar, 14 chipped stone tools, which all confirm that the life was intensive at the site during the first quarter of the $4^{\text {th }}$ millennium BCE. Otherwise, lavishly decorated Early Eneolithic pottery at the site has a higher representation compared to the site of Bubanj during their contemporary existence, which could indicate that the population at the site of Velika Humska Čuka had access to certain mineral deposits or other resources for the production of natural paint, or on the other hand possessed staple natural resources (flint, copper) suitable for exchange for lavishly decorated vessels.

The youngest phase of house 3 dated to the first quarter of the $4^{\text {th }}$ millennium BCE was destroyed in a fire with all of the vessels stored in two pits. It is not clear whether the house was intentionally burned due to a sacrifice ritual, mentioned by certain authors [59;60], or perished in an accidental fire. The theory that the house was burnt amid a sudden conflict seems at the moment as the least possible, since access to the site is hard and the undetected intrusion is impossible. In case that the intrusion was detected, the inhabitants of the settlement would have time to carry some of the vessels that were, however, burnt with the house.

Following this period, both of the sites were inhabited for several centuries and during the third quarter of the $4^{\text {th }}$ millennium $\mathrm{BCE}$, solely the site of Bubanj remains inhabited by the bearers of the Cernavodă IIIBoleraz-Baden cultural phenomenon, whose material culture completely differs from the preceding Bubanj-Hum I group (Cental Balkans variant of the BSK complex), which indicates that the inhabitants are newcomers from the northeast, the mother territory of the group [61]. For some reason, these newcomers did not settle at Velika Humska Čuka, possibly since they had no need to fortify it and defend it. The settling of the aforementioned group lasted for approximately 80 years (63.7\% probability) [38], as during the final quarter of the $4^{\text {th }}$-millennium BCE bearers of the Cotofeni-Kostolac group settle at the site, with the material culture differing from both the preceding and the Bubanj-Hum I group. Bearers of this group are likewise of foreign origin [61], and their settling at the site of Bubanj is longer than their predecessors, judging by the absolute dates, stratigraphy, and the architecture of the settlement. According to Bayesian modeling, the bearers of the Coțofeni-Kostolac group inhabited Bubanj for between 265 and 461 years [40, p. 1175], yet the modeling of all of the dates from the previous and following periods indicate that the first date is more probable [37, p. 241-243]. The stylistic and typological characteristics of their pottery are analogous within the entire territory of this group from Pannonia to the Southern Morava Region, although certain local elements have been noted at the site of Bubanj, especially within the latest phase of the group. Those local elements will provide a basis for the emergence of the following Bubanj-Hum II group, which both culturally and chronologically evolves from the Coțofeni-Kostolac group.

Identical local elements, together with the pottery typical for the Cotofeni-Kostolac group also occur at the site of Velika Humska Čuka, which points out that even after several centuries of hiatus, the site is once again inhabited by the bearers of the CoțofeniKostolac group. Unfortunately, the site yielded no period-related architecture or enclosed features suitable for radiometric sampling, which disables any comparisons of the sites during that period. Identical forms and ornamentation on both sites have been recorded in the following period, the Bubanj-Hum II group, which is by means of the house 
remains from Velika Humska Čuka dated to the second quarter of the $3^{\text {rd }}$ millennium. Humble remains of a residential structure from Velika Humska Čuka indicate that the residential architecture in this period was similar on both of the sites, while the comparisons of other spheres of life are impossible at the moment due to the lack of data.

Starting from this period, both of the sites remain continuously inhabited for several centuries, throughout the Bronze Age, with almost identical stylistic and typological characteristics of pottery, indicating prevailing close ties and contact between the inhabitants of these two sites during the Bronze Age.

In literature, the sites of Velika Humska Čuka and Bubanj are considered as one of the most important prehistoric sites in the Central Balkans. Owing to the results of the archeological excavation of the eponymous sites, M. Garašanin defined cultural groups Bubanj-Hum I-III more than half a century ago, and for the first time scientifically interpreted the cultural and chronological setting of the Central Balkans during the Eneolithic and the Early Bronze Age [30; 35]. After more than half a century, with all of the modern analyses and large-scale excavations of these sites and period-related sites in the Central Balkans in the last few decades, the definition set by M. Garašanin remains scientifically completely justified.

\section{Conclusion}

With their distinct stratigraphy, geostrategic position, continuity in settling, and the scale of research, the sites of Velika Humska Čuka and Bubanj represent one of the most important sites for the research of the Eneolithic and Bronze Age in the Central Balkans. Unfortunately, the site of Bubanj is completely devastated by human activities.
On the other hand, the site of Velika Humska Čuka, which is still being excavated, is only partially researched and could offer an abundance of important data on the emergence and the development of the Eneolithic in the region.

The opposed topographic characteristics of sites of Bubanj and Velika Humska Čuka and the complementarity of soil types and other resources suggest a high degree of integration and cooperation between adjacent settlements, emphasized territoriality, and high control of surrounding landscape, communications, and resources. The stated pattern of two adjacent concurrent and cooperative small settlements with complementary roles and functions ${ }^{1}$ [13], was a constitutive element of the eneolithisation process (4700/4650-4400/4350 cal BCE), which coincides with the first steppe migration [6, p. 291-292; 62, p. 48; 63, p. 277-338), Varna 1 necropolis phenomenon [64;65], formation of new social groups (e. g. BSK in Serbia, Bulgaria, and Romania, Tiszapolgar and Bodrogkerestur in Hungary, Karanovo VI in Bulgaria and Rachmani in Greece), the adoption of a series of social and economic innovations and the parallel lasting of strong Late Neolithic traditions ${ }^{2}$, that took place on a vast territory between the Middle Danube Region and the banks of the Black Sea.

Дата поступления в редакцию 24.08.2021

\footnotetext{
Milanović D. The interply between lowland and highland zones: Engaging the landscape of eastern Serbia and western Bulgaria in the second half of the 5th millennium BCE. In: Gori M., Hellmuth-Kramberger A., Krapf T., Recchia G.,eds. Archaeology of Mountainous Landscapes in Balkan Prehistory. Universitätsforschungen zur prähistorischen Archäologie, Rudolf Habelt, Bonn (готовится к печати в 2022 г.).

2 Milanović D. The Copper Age in the Central Balkans. In: Parkinson W. A., Gyucha A., Galaty M.,eds. Oxford Handbook of Balkan Prehistory. Oxford, Oxford University Press (готовится к печати в 2022 г.).
}

\section{REFERENCES}

1. Garašanin M. Centralnobalkanska zona. In: Benac A., ed. Praistorija jugoslavenskih zemalja II, Neolitsko doba. Sarajevo, 1979, pp. 79-212.

2. Jovanović B. Gradac Phase in the Relative Chronology of the Late Vinča Culture. In: Старинар, 1994, vol. 18, pp. 1-10. 
3. Tasić N. Eneolithic cultures of Central and West Balkans. Belgrade, 1995. 205 p.

4. Borić D. The End of the Vinča World: Modelling the Neolithic to Copper Age Transition and the Notion of Archaeological Culture. In: Hansen S., Raczky P., Anders A., Reingruber A., eds. Neolithic and Copper Age between the Carpathians and the Aegean Sea. Chronologies and technologies from the $6^{\text {th }}$ to the $4^{\text {th }}$ millennium BCE, Archäologie in Eurasien 31. Bonn, 2015, pp. 157-217.

5. Nikolova L., Manzura I., Schuster C. The Balkans in Later Prehistory, Periodization, Chronology and Cultural Development in the Final Copper and Early Bronze Age (Fourth and Third Millennia BC). Oxford, 1999. $442 \mathrm{p}$.

6. Todorova H. Prehistory of Bulgaria. In: Gramenos D. V., ed. Recent Research in the Prehistory of the Balkans. Thessaloniki, Athens, 2003, pp. 257-317.

7. Georgieva P. Periodization of the Krivodol - Sâlcuta - Bubanj culture. In: Срејовић Д., Тасић Н., eds. Винча и юен свет, Међународни скуп, Подунавље између 6000 и 3000 г. пре нове ере. Београд, 1990, pp. 167-173.

8. Borić D. Absolute Dating of Metallurgical Innovations in the Vinča Culture of the Balkans. In: Kienlin L., Roberts B. W.,eds. Metals and Societies, Studies in honour of Barbara S. Ottaway. Vol. 169. Bonn, 2009, pp. 191-245.

9. Radivojević M., Grujić J. Community structure of copper supply networks in the prehistoric Balkans: An independent evaluation of the archaeological record from the $7^{\text {th }}$ to the $4^{\text {th }}$ millennium BCE. In: Journal of Complex Networks, 2018, no. 6, pp. 106-124.

10. Bulatović A., Bankoff A., Powell W., Filipović V. Some remarks on the genesis of the Early Eneolithic in the Central Balkans. In: Старинар, 2020, vol. 70, pp. 9-40.

11. Ристић-Опачић J. Топографско-хронолошке карактеристике насеља винчанске културе на територији Србије. In: Гласник Српског археолошког друштва, 2005, vol. 21, pp. 71-112.

12. Kapuran A., Bulatović A., Milanović D. Settlement pattern changes during the Central Balkans Copper Age. In: Deitz S., Mavridis F., Tankosić Ž., Takaoglu T., eds. Communities in Transition: The Circum-Aegean later Neolithic stages (5000/4800-3200/3000 BCE). Vol. 20. Oxford, Philadelphia, Oxbow books, 2018, pp. 77-88.

13. Milanović D. Insight into the regional distribution and geographic setting of the Vinča and Bubanj-SălcuTaKrivodol settlements in the Central Balkans and its implication. In: Старинар, 2019, vol. 69, pp. 61-84.

14. Трипковић Б. Домаћинство и заједница. Куће и насеобинске историје у касном неолиту Централног Балкана. Београд, 2013. 319 p.

15. Borić D., Hanks B., Šljivar D., Kocić M., Bulatović J., Griffiths S., Doonan R., Jacanović D. Enclosing the Neolithic World. A Vinča Culture Enclosed and Fortified Settlement in the Balkans. In: Current Anthropology, 2018, no. 59 (3), pp. 336-346.

16. Chapman J., Gaydarska B., Hardy K. Does enclosure make a difference? A view from the Balkan. In: Harding A., Sievers S., Venclov6 N.,eds. Enclosing the Past: Inside and Outside in Prehistory. Sheffield Archaeological Monographs 15. Sheffield, 2006, pp. 20-43.

17. Ivanova M. Tells, Invasion Theories and Warfare in fifth millennium B.C. North-Eastern Bulgaria. In: Pollard T., Banks I.,eds. War and Sacrifice, Studies in the Archaeology of Conflict. Leiden \& Boston, Brill, 2007, pp. 33-48.

18. Zäuner S. P. The Dark Side of the Chalcolithic. Evidence for Warfare at Tell Yunatsite? An anthropological approach. In: Boyadzhiev J., Terzijska-Ignatova S., eds. The Golden Fifth Millennium. Thrace and its Neighbour Areas in the Chalcolithic. Sofia, NIAM-BAS, 2011, pp. 49-56.

19. Sherratt A. G. Plough and pastoralism: aspects of the Secondary Products Revolution. In: Hodder I., Isaac G., Hammond N., eds. Pattern of the Past. Cambridge, Cambridge University Press, 1981, pp. 261-306.

20. Demoule J-P., Perlès C. The Greek Neolithic: a new review. In: Journal of World Prehistory, 1993, no. 7, pp. 355-416.

21. Jovanović B. Metalurgija eneolitskog perioda Jugoslavije. Beograd, Arheoloљki institut, 1971. 119 p.

22. Parkinson W. A., Yerkes R. W., Gyucha A. The Transition from the Neolithic to the Copper Age: Excavations at Vésztő-Bikeri, Hungary, 2000-2002. In: Journal of Field Archaeology, 2004, no. 29 (1/2), pp. 101-121.

23. Hansen S. Innovative Metals: Copper, Gold and Silver in the Black Sea Region and the Carpathian Basin During the $5^{\text {th }}$ and $4^{\text {th }}$ Millennium BC. In: Burnmeister S., Hansen S., Kunst M., Müller Schees- 
sel N.,eds. Metal Matters: Innovative Technologies and Social Change in Prehistory and Antiquity. Rahden, Verlag Marie Leidorf, 2013, pp. 137-167.

24. Kienlin T. L., Aspects of metalworking and society from the Black Sea to the Baltic Sea from the fifth to the second millennium BC. In: Roberts B. W., Thornton C. P., eds. Archaeometallurgy in Global Perspective: Methods and Syntheses. NewYork, Springer-Verlag, 2014, pp. 447-472.

25. Antonović G., Mrvić V. Zemljišta sliva Nišave. Beograd, Institut za zemljište, 2008. 33 p.

26. Калућеровић 3. Кременац код Ниша: Палеолитско налазиште, хроника ископавања. In: Старинар, 1996, по. 47, pp. 289-290.

27. Богосављевић-Петровић В. Праисторијски рудници на централном Балкану. In: Зборник Народног музеја, 2005, по. 18/1, pp. 79-113.

28. Šarić J. Lower Paleolithic Site Kremenac near Village Rujnik. In: Старинар, 2011, vol. 61, pp. 7-31.

29. Гарашанин М., Ђурић Н. Бубањ и Велика Хумска Чука. Ниш: Народни музеј, 1983. 39 р.

30. Garašanin M. Ausgrabungen in Bubanj bei Niš (Serbisches Moravagebiet). In: Germania, 1957, vol. 35, Heft 3-4, pp. 198-207.

31. Garašanin M. Kontrollgrabung in Bubanj bei Niš. In: Praehistorische Zeitschrift, 1958, no. 36, pp. 223 244.

32. Гарашанин М. Ископавања на Бубњу код Ниша, претходни извештај за 1954-1956. годину. In: Старинар, 1958, vol. 7-8,pp. 269-274.

33. Garašanin M. Neolithikum und Bronzezeit in Serbien und Makedonien. In: Bericht der Römisch-Germanischen Kommission, 1958, vol. 39, p. 1-130.

34. Garašanin M., Bubanj kod Niša-Naselje ranog bronzanog doba. In:Arheološki pregled, 1959, vol. 1, pp. 26-30.

35. Garašanin M. Zur Chronologischen und Kulturellen Wertung der Bubanj-Funde. In: Jahrbuch des Römisch-Germanischen Zentralmuseums Mainz, 1982, vol. 26, pp. 154-166.

36. Милановић Д., Трајковић-Филиповић Т. Стара ископавања на локалитету Бубањ:праисторијско вишеслојно налазиште код Ниша. Ниш, Народни музеј, 2015. 144 p.

37. Bulatović A., Milanović D. Bubanj, the Copper and the Early Bronze Age Tell in Southeastern Serbia. Mitteilungen der Prähistorischen Kommission, Band 90. Austrian Academy of Sciences Press, Wien $2020,418 \mathrm{p}$.

38. Bulatović A., Vander Linden M. Absolute Dating of Copper and Early Bronze Age Levels at the Eponymous Archaeological Site Bubanj (Southeastern Serbia). In: Radiocarbon, 2017, vol. 59 (4), pp. 1047 1065.

39. Bulatović A., Gori M., Vander Linden M. New AMS dates as a contribution to the absolute chronology of the Early Eneolithic in the central Balkans. In: Старинар, 2018, vol. 68, pp. 19-32.

40. Bulatović A., Gori M., Vander Linden M. Radiocarbon Dating the $3^{\text {rd }}$ Millennium BC in the Central Balkans: a re-examination of the Early Bronze Age sequence. In: Radiocarbon, 2020, vol. 62, no. 5, pp. 1163-1191.

41. Fewkes V. J. Neolithic sites in the MoravoDanubian area (Eastern Yugoslavia). In: Bulletin of the American School of Prehistoric Research, 1936, no. 12, pp. 5-81.

42. Гарашанин М., Гарашанин Д. Нова ископавања на Великој Хумској Чуки код Ниша. In: Старинар, 1959,vol. 9-10, pp. 243-254.

43. Булатовић А., Милановић Д. Велика Хумска Чука, истраживања 2009. године: прилог проучавању стратиграфије енеолита и бронзаног доба у југоисточној Србији. In: Гласник Сриског археолошког друштва 30/2014, 2015, pp. 163-188.

44. Orssich De Slavetich A. Bubanj: eine prähistorische Ansiedlung bei Niš. Mitteilungen der Prähistorischen Kommission, Band 4/1-2. Wien, 1940. 65 p.

45. Bulatović A.Corded Ware in the Central and Southern Balkans: A Consequence of Cultural Interaction or an Indication of Ethnic Change? In: Journal of Indo-European Studies, 2014, vol. 42, pp. 101-143.

46. Милановић Д. Насеље Чернавода III културе на локалитету Бубањ. In: Старинар, 2011, vol. 61, pp. 101-119.

47. Milanović D. Cultural and chronological position of the Chalcolithic horizons III and IV at Bubanj site: excavations from 1954. In: Archaeologia Bulgarica 2013, no. 17/2, pp. 1-16.

48. Jovanović B. Obredi sahranjivanja u kostolačkoj grupi. In: Godišnjak Centra za balkanološka ispitivanja ANUBIH, 1976, vol. 13, pp. 131-142. 
49. Николић Д. Енеолитска насеља у околини Мајданпека. In: Лазић M.,ed. Археологија источне Србије, научни скуп одржан у Београду и Доюем Милановиу 1995 год. Београд, 1997, pp. 197-210.

50. Nikolić D. Kostolačka kultura na teritoriji Srbije. Beograd, 2000. 108 p.

51. Капуран А., Булатовић А. Културна група Коцофени-Костолац на територији источне Србије. In: Старинар, 2012,vol. 62,pp. 63-94.

52. Petrović J., Jovanović B. Gomolava, naselja kasnog eneolita. Beograd, Novi Sad, 2002, 387 p.

53. Булатовић А. Феномен праисторијских ритуалних јама, неколико примера са централног Балкана. In: Старинар, 2015, vol. 65, pp. 7-35.

54. Bulatović J. Preliminary Report on Animal Bones from Bubanj. In: Bulatović A., Milanović D. Bubanj, the Copper and the Early Bronze Age Tellin Southeastern Serbia. Mitteilungen der Prähistorischen Kommission, Band 90. Wien, Austrian Academy of Sciences Press, 2020, pp. 329-337.

55. Sørensen Østergaard J. Animal bones. In: Merkyte I. Lîga Copper Age strategies in Bulgaria. Acta archaeologica, 2005, vol. 76 (1), pp. 132-139.

56. Berciu D. Contribuții la problemele neoliticului in Rominia in lumina noilor cercetâri. București, Editura Academiei Republicii Populare Romine, 1961. 593 p.

57. Roman P. Strukturanderungen des Endaneolithikums im Donau-Karpaten-Raum. In: Dacia, 1971, vol. 15 , pp. 31-169.

58. Георгиева П. Материали от претходния период между каменномедната и бронзовата епоха от Северна България. In: Археология, 1987,vol. 1. pp. 1-15.

59. Stevanović M. The Age of Clay: The Social Dynamics of House Destruction. In: Journal of Anthropological Archaeology, 1997, vol. 16, pp. 334-395.

60. Chapman J. Deliberate house-burning in the prehistory of central and eastern Europe. In: Glyfer och arkeologiska rum: En vänbok till Jarl Nordbladh. Göteborg, University of Göteborg Press, 1999, pp. 113-126.

61. Bulatović A., Kapuran A. Cultural contacts between communities of southwestern Romania and the central Balkans in the fourth millennium BC. In: Cristian I. P., ed. The Carpathian Basin and the Northern Balkans between 3500 and 2500 BC: Common Aspects and Regional Differences, Annales Universitatis Apulensis: Series Historica, 2017, vol. 20/II, pp. 183-201.

62. Anthony D. W. The Rise and fall of Old Europe. In: Anthony D. W., Chi J. Y., eds. The Lost World of Old Europe: The Danube Valley, 5000-3500 BC. Princeton University Press, 2010, pp. 29-57.

63. Gimbutas M. The first Wave of Euroasian Steppe Pastorialists into Copper Age Europe. In: Journal of Indoeuropean Studies, 1977, vol. 5. pp. 277-338.

64. Chapman J., Higham T., Slavchev V., Gaydarska B., Honch N. The Social Context of the Emergence, Development and Abandonment of the Varna Cemetery, Bulgaria. In: European Journal of Archaeology,2006, no. 9 (2-3), pp. 159-183.

65. Krauß R., Schmid C., Kirschenheuter D., Abele J., Slavchev V., Weninger B. Chronology and development of the Chalcolithic necropolis of Varna I. In: Documenta Praehistorica, 2017, vol. 44, pp. $282-$ 305.

\section{INFORMATION ABOUT THE AUTHORS}

Aleksandar P. Bulatović - scientific advisor, Institute of Archaeology; e-mail: abulatovic3@gmail.com

Dragan P. Milanović - scientific advisor, Institute of Archaeology;

e-mail: draganarh@gmail.com

\section{ИНФОРМАЦИЯ ОБ АВТОРАХ}

Александр Булатович Петар- научный советник Института археологии; e-mail: abulatovic3@gmail.com

Драган Миланович Ратомир- научный сотрудник Института археологии; e-mail: draganarh@gmail.com 


\section{FOR CITATION}

Bulatović A., Milanović D. The cultural and chronological context of sites of Bubanj and Velika Humska Čuka near Niš (Southeastern Serbia) and their significance for understanding the emergence and development of the Central Balkans Eneolithic. In: Bulletin of Moscow Region State University. Series: History and Political Sciences, 2021, no. 5, Circumpontica, iss. III, pp. 36-64.

DOI: $10.18384 / 2310-676 \mathrm{X}-2021-5-36-64$

\section{ПРАВИЛЬНАЯ ССЫЛКА НА СТАТЬЮ}

Булатович А., Миланович Д. Культурно-хронологический контекст памятников Бубань и Велика Хумска-Чука недалеко от Ниша (Юго-восточная Сербия) и его значение для понимания возникновения энеолита центральных балкан // Вестник Московского государственного областного университета. Серия: История и политические науки. 2021. № 5. Циркумпонтика. Вып. III. С. 36-64. DOI: 10.18384/2310-676X-2021-5-36-64 